CENTRO UNIVERSITÁRIO FEI

AGNES SILVERIO

ANÁLISE DA IMPLEMENTAÇÃO DE UM PROGRAMA DE WORLD CLASS MANUFACTURING EM RELAÇÃO AOS PRINCIPIOS E PRÁTICAS CONCEITUAIS 
AGNES SILVERIO

\section{ANÁLISE DA IMPLEMENTAÇÃO DE UM PROGRAMA DE WORLD CLASS MANUFACTURING EM RELAÇÃO AOS PRINCIPIOS E PRÁTICAS CONCEITUAIS}

Dissertação apresentada ao Centro Universitário $\mathrm{FEI}$, como parte dos requisitos necessários para obtenção do título de mestre em engenharia mecânica. Orientado pelo Professor Dr. Dário Henrique Alliprandini.

São Bernardo do Campo 
Silverio, Agnes.

ANÁLISE DA IMPLEMENTAÇÃO DE UM PROGRAMA DE WORLD CLASS MANUFACTURING EM RELAÇÃO AOS PRINCÍPIOS E PRÁTICAS CONCEITUAIS / Agnes Silverio. São Bernardo do Campo, 2019. 63 p. : il.

Dissertação - Centro Universitário FEI.

Orientador: Prof. Dr. Dário Henrique Alliprandini.

1. Fabricação de classe mundial.. 2. Manufatura enxuta.. 3 . Implementaçăo.. I. Alliprandini, Dário Henrique , orient. II. Título.

Elaborada pelo sistema de geração automática de ficha catalográfica da FEI com os dados fornecidos pelo(a) autor(a). 
centro

Título do Trabalho: Análise da implementação de um programa de world class manufacturing em relação aos principios e práticas conceituais.

Área de Concentração: Produção

Orientador: Prof. Dr. Dário Henrique Alliprandini

Data da realização da defesa: 29/04/2019

ORIGINAL ASSINADA

Avaliação da Banca Examinadora:

São Bernardo do Campo,

\section{MEMBROS DA BANCA EXAMINADORA}

Prof. Dr. Dário Henrique Alliprandini

Profa Dra Ana Paula Vilas Boas Viveiros Lopes

Prof. Dr. Geraldo Cardoso de Oliveira Neto
Ass.

Ass.

Ass.

A Banca Julgadora acima-assinada atribuiu ao aluno o seguinte resultado:

APROVADO $\bigotimes$

REPROVADO $\square$

\section{VERSÄO FINAL DA DISSERTACÄO}

APROVO A VERSÃo FINAL DA DISSERTAÇÃo EM QUE FORAM INCLUÍDAS AS RECOMENDAÇÕES DA BANCA EXAMINADORA
Aprovação do Coordenador do Programa de Pós-graduação Prof. Dr. Rodrigo Magnabosco 
Dedico este trabalho à minha mãe Teresa Donadio Silvério, às minhas irmãs Isadora e Rachel Silverio, meu sobrinho Matheus Silverio, meu pai Elias Silverio, André Augusto, aos meus amigos e aos meus queridos antepassados. 


\section{AGRADECIMENTOS}

A presente dissertação de mestrado não poderia chegar a conclusão sem o precioso apoio de várias pessoas. Em primeiro lugar, não posso deixar de agradecer ao meu orientador, Professor Doutor Dário Henrique Alliprandini, por toda a dedicação, empenho e sentido prático com que sempre me orientou neste trabalho e em todos aqueles que realizei durante o desenvolvimento do mestrado.

Muito obrigada por ter corrigido quando necessário sem nunca me desmotivar. Desejo igualmente agradecer a todos os meus professores do Mestrado, especialmente a Professora Doutora Ana Paula Lopes, que foi minha co-orientadora neste trabalho.

Agradeço aos funcionários da biblioteca da FEl, que foram sempre solícitos, e todos que me ajudaram a ultrapassar um grande obstáculo.

Por último, mas não menos importante, quero agradecer à minha família e amigos pelo apoio incondicional que me deram. 
"Por mais rigoroso que seja o inverno, ele não tarda em se tornar primavera"

Daisaku Ikeda 


\section{RESUMO}

Na fabricação de classe mundial ou WCM (World Class Manufacturing), o foco é a melhoria contínua. Para o WCM as perdas ou desperdícios são vistos e tratados como oportunidades de ganhos que se relacionam diretamente com desempenho. Este trabalho teve como objetivo analisar a implementação de um programa World Class Manufacturing com base nas práticas, princípios e pilares conceituais, motivado pela necessidade das empresas se manterem competitivas num mercado de constantes mudanças e considerando a importância da eliminação de qualquer fonte de desperdício. Este trabalho apresenta um estudo bibliométrico, o qual deu suporte ao desenvolvimento teórico e à pesquisa de campo. O método de pesquisa adotado foi o estudo de caso em duas empresas de um mesmo grupo, porém em segmentos diferentes. A empresa $A$ atua no setor automobilístico e a empresa B atua no setor siderúrgico, ambas com certificação bronze em WCM. Foram realizadas entrevistas semiestruturadas e análise de documentos. Os resultados foram analisados intra e inter casos. Clonclui-se que os principais conceitos da literatura estão presentes nas duas empresas, porém, com diferentes graus de abrangência ou maturidade. Pode-se verificar que a fundação do WCM observada nas empresas estudadas é um diferencial para obtenção dos resultados esperados.

Palavras-chave: Fabricação de classe mundial. Manufatura enxuta. Implementação. 


\begin{abstract}
In world class manufacturing, WCM, the focus is continuous improvement. For WCM, loses are seen and treated as opportunities that relate directly to performance. This study focuses to analyze the implementation of a World Class Manufacturing program based on the practices, principles and conceptual pillars, motivated by the need of companies to remain competitive in a market of constant changes and considering the importance of eliminating any source of loses. This work presents a bibliometric study, which supported theoretical development and field research. The research method adopted was the case study in two companies of the same group, but in different segments. Company $A$ operates in the automotive sector and Company B operates in the steel sector, both with bronze certification in WCM. Semistructured interviews and document analysis were carried out. The results were analyzed intra- and inter-case. It was concluded that the main concepts of the literature are present in the two companies, however, with different degrees of comprehensiveness or maturity. It was verified that the foundation of the WCM observed in the companies studied is a differential to obtain the expected results. Keywords: World Class Manufacturing. Lean manufacturing. Implementation.
\end{abstract}




\section{LISTRA DE ILUSTRAÇÕES}

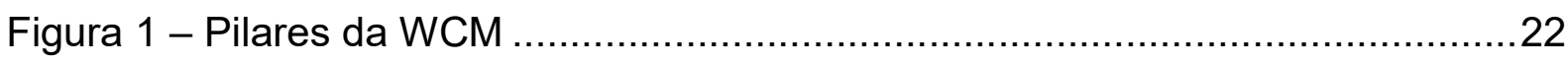

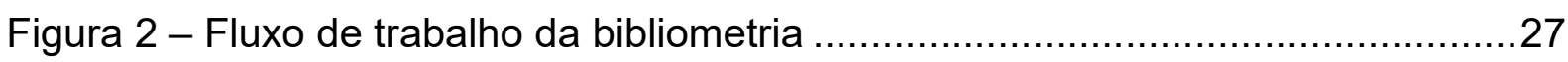

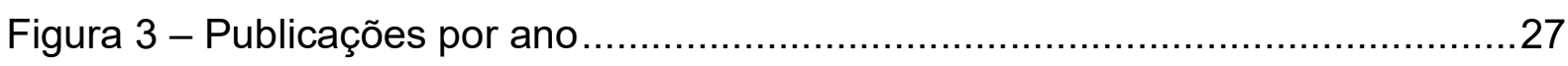

Figura 4 - Evolução das citações dos 16 artigos mais citados. ...........................29

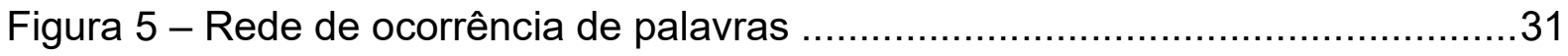

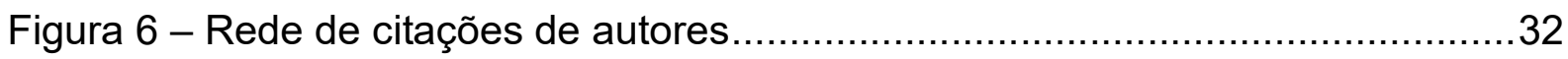

Figura 7 - Programa de WCM nas empresas A e B ...................................... 35

Figura 8 - Estrutura do desdobramento da política de WCM nas empresas A e B...36 Figura 9 - Gerenciamento dos Indicadores de desempenho na política de WCM nas

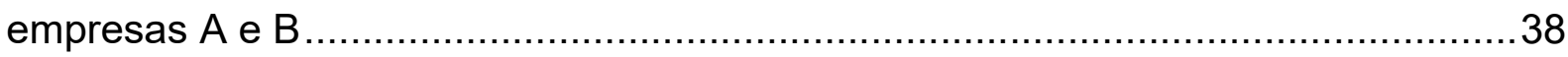

Figura 10 - O que se espera do Programa de WCM nas empresas A e B ............40

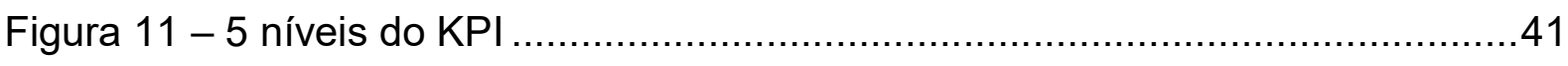

Figura 12 - Exemplificação do gráfico de ponte..........................................42

Figura 13 - Exemplo de gráfico de ponte espelhado ........................................43 


\section{LISTA DE TABELAS}

Tabela 1 - Publicações por periódico e ano. .28

Tabela 2 - Artigos mais citados 


\section{LISTA DE QUADROS}

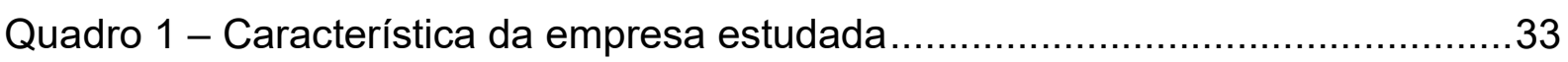

Quadro 2 - Descrição dos componentes da fundação e os pilares do templo WCM 37 


\section{LISTA DE SIGLAS}

$\begin{array}{ll}\text { EQF } & \text { Engenheiro de Qualidade do Fornecedor } \\ \text { FMEA } & \text { Failure Mode and Effect Analysis } \\ \text { JIT } & \text { Just In Time } \\ \text { KPI } & \text { Key Performance Indicator } \\ \text { OEE } & \text { Overall Equipment Effectiveness } \\ \text { OPI } & \text { Operational Performance Indicators } \\ \text { OTIF } & \text { On-Time-In-Full } \\ \text { QA } & \text { Quality Assurance } \\ \text { SFIS } & \text { Shop Floor Integration System } \\ \text { TI } & \text { Tecnologia de Informação } \\ \text { WCM } & \text { World Class Manufacturing } \\ \text { WCP } & \text { World Class Purchase } \\ \text { WCSC } & \text { World Class Supply Chain }\end{array}$




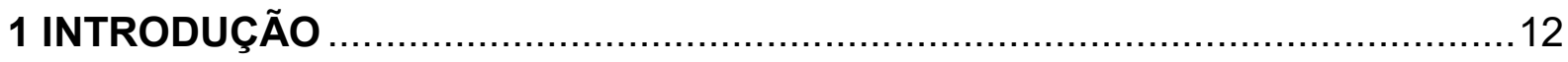

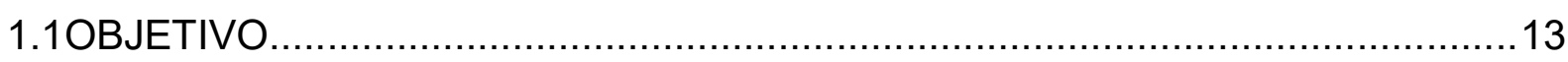

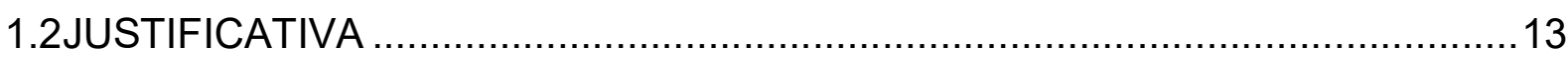

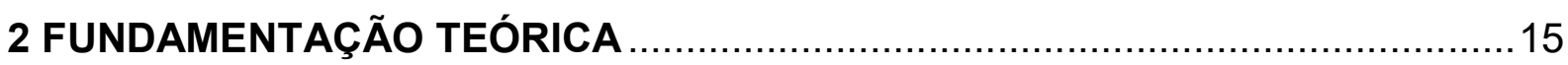

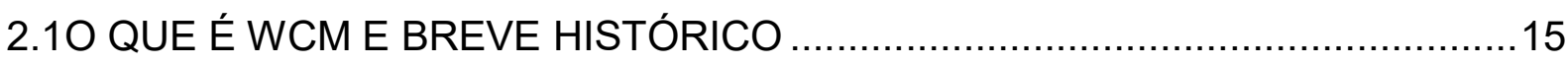

2.2CONSIDERAÇÕES RELEVANTES PARA IMPLEMENTAÇÃO DO WCM ...........16

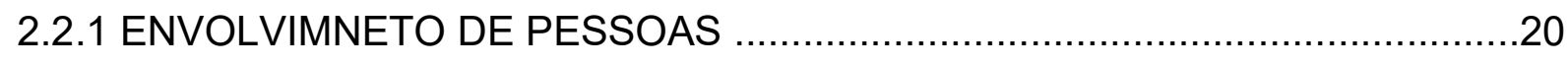

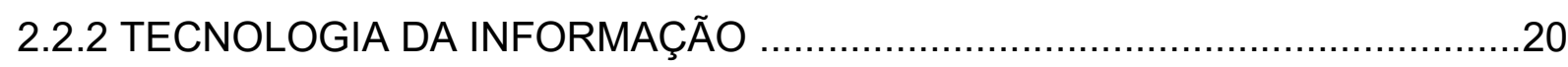

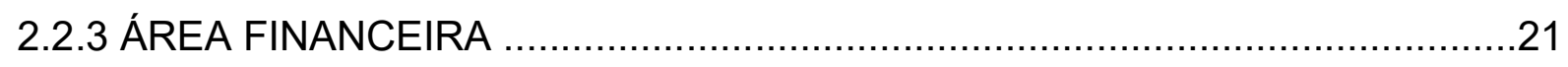

2.3 AS 6 PRÁTICAS - HAYES E WHEELWRIGHT (1984)................................... 19

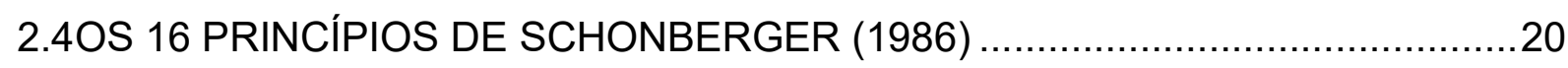

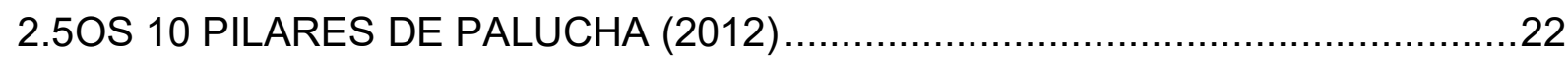

2.6 QUADRO COMPARATIVO DAS TRÊS REFERÊNCIAS CONCEITUAIS DA

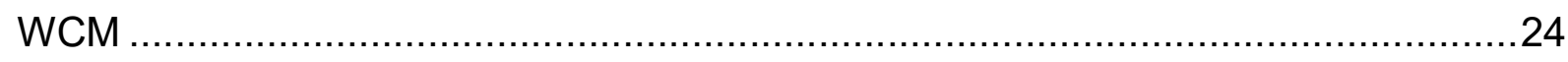

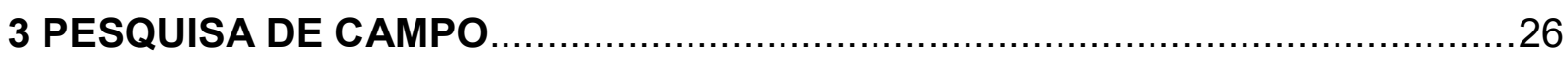

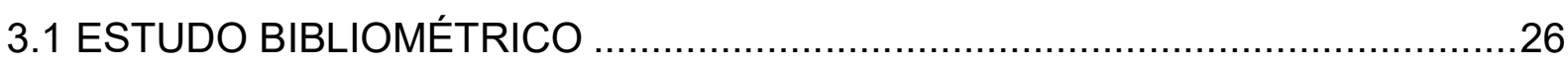

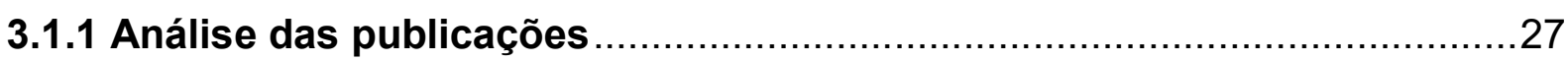

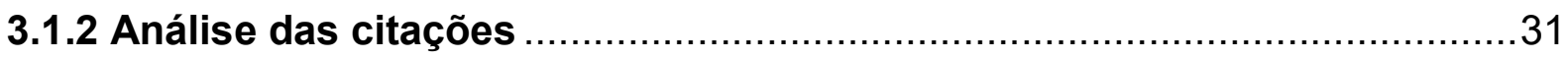

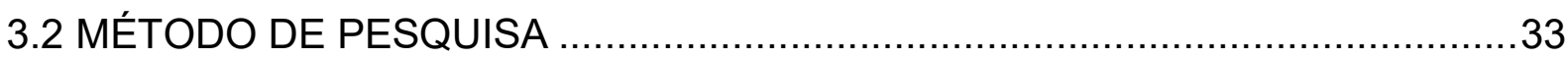

3.3 DESCRIÇÃO DO PROGRAMA DE WCM NAS EMPRESAS A E B...................34

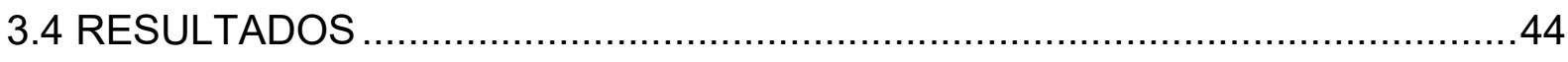

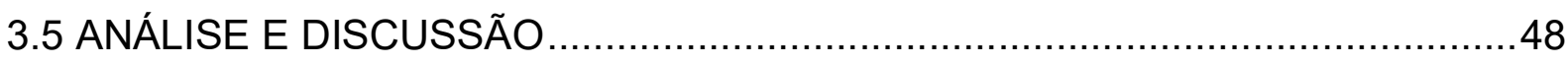

3.5.1 Análise com base nas 6 práticas da WCM de Hayes e Wheelwright (1984) .48

3.5.2 Análise com base nos 16 princípios de Schonberger (1986) …..............50

3.5.3 Análise com base nos 10 Pilares de Palucha (2012) ..............................54

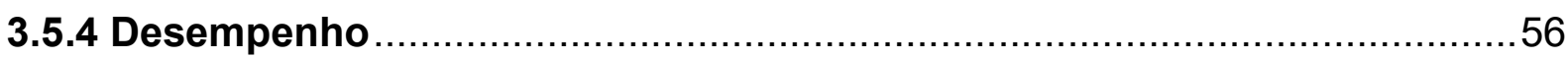

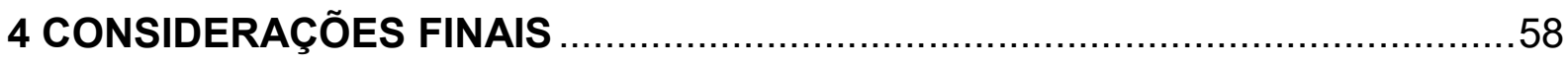

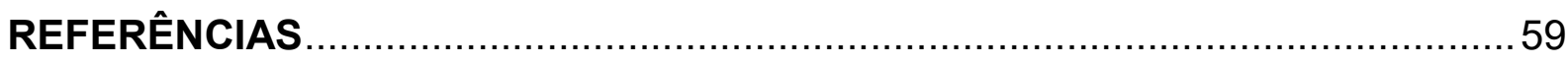





\section{INTRODUÇÃO}

O termo "fabricação de classe mundial" ou WCM (World Class Manufacturing) foi usado pela primeira vez por Hayes e Wheelwright em 1984. O WCM é um conjunto de conceitos, princípios, políticas e técnicas baseadas na produção enxuta. Com o processo de globalização da economia, as empresas passaram a buscar meios de fortalecimento para se manterem competitivas no mercado, mantendo-se à frente de seus concorrentes (FREITAS; BARROS FILHO, 2016).

Tornar-se uma firma de fabricação de classe mundial é a meta de muitas empresas e isso pode significar ser a melhor em seu setor industrial ou até mesmo globalmente. O importante é obter um nível de desempenho que proporcione a capacidade de ter sucesso e sobreviver no futuro, estabelecendo programas de melhoria apropriados e alinhados com as mudanças da manufatura (MUDA; HENDRY, 2002).

Para alguns gestores, a qualidade é o principal fator que afeta o desempenho de uma organização em relação aos seus concorrentes. Um importante diferencial para as empresas para as empresas de manufatura ao longo dos anos foi investir em melhoria contínua tanto na qualidade do produto quanto na qualidade do processo (SLACK; CHAMBERS; JOHNSTON, 2002).

$O$ desenvolvimento da economia de qualquer país é apoiado pelo crescimento da produção de sua indústria. A excelência de fabricação e melhoria contínua desempenham papéis importantes no progresso de qualquer nação. Neste contexto, a adoção ou implementação da filosofia de fabricação de classe mundial é imperativa e fornece uma vantagem competitiva significativa para uma organização sobre seus concorrentes, pois oferece benefícios como redução de custos, aumento da qualidade, melhoria em posição competitiva, menor volume de negócios pessoal, melhoria no desempenho em geral (SUNNAPWAR; KODALI, 2006).

Um sistema eficaz de medição de desempenho fornece às organizações a magnitude e direção do progresso em direção à excelência. Os critérios de medidas e padrões do sistema de medição do desempenho estabelecidos sobre os objetivos estratégicos atuais devem ser dinâmicos e mudar com a condições ambientais internas e externas do negócio. Mecanismos formalizados para a troca de informações de medição de desempenho são necessários para assegurar as 
ligações entre o desempenho e o nível da divisão e da planta de sistemas de medição. Uma cultura corporativa propícia a cooperação interfuncional para criar ligações eficazes que promovem a coordenação organizacional é fundamental (LOCKAMY; COX, 1995).

O comprometimento da alta gerência é o principal fator para implementar o WCM, e reflete diretamente na melhora do desempenho da organização em termos de gestão do conhecimento, treinamento de funcionários, inovação tecnológica e envolvimento do cliente e funcionários. Melhorias adicionais nos fatores acima mencionados favorecem a capacitação dos funcionários e melhoraram indicadores operacionais como custo, qualidade, velocidade, flexibilidade, saúde e segurança ambiental, planejamento e controle de produção, gerenciamento de fornecedores da organização, o que leva à melhoria do atendimento ao cliente e satisfação, que finalmente se converte em crescimento da empresa (DIGALWAR; JINDAL; SANGWAN, 2013).

\subsection{OBJETIVO}

Esta pesquisa tem o seguinte objetivo analisar em empresas de segmento automotivo e siderúrgico a implementação de um programa World Class Manufacturing com base nas práticas, princípios e pilares conceituais.

\subsection{JUSTIFICATIVA}

O cenário mercadológico se mostra um ambiente competitivo e as firmas buscam atender às necessidades dos clientes. Os processos de transformações ocorridos buscaram alternativas para identificar e entender as necessidades dos clientes de forma mais eficiente, flexível, com produtos de alto valor agregado, de menor custo e atendimento aos prazos (LEAN INSTITUTE BRASIL, 2019).

Notou-se a necessidade de ajustar os processos de produção aos requisitos de um mercado competitivo que requer uma análise das atividades sob a perspectiva do fluxo de materiais e informações, eliminação de qualquer fonte de desperdício. Para o WCM as perdas ou desperdícios são vistos e tratados como oportunidades de ganhos que se relacionam diretamente no desempenho. 
WCM é fundamentado na melhoria contínua, o que requer constante aprimoramento de estudo e acompanhamento do que as empresas vêm aplicando em prol de seus objetivos rumo a excelência, o que justifica este estudo na contribuição da teoria e prática. 


\section{FUNDAMENTAÇÃO TEÓRICA}

Este capítulo apresenta uma revisão sobre os principais conceitos relacionados à manufatura de classe mundial ou World Class Manufacturing (WCM). O termo "fabricação de classe mundial" foi usado pela primeira vez por Hayes e Wheelwright em 1984.

Os objetivos da WCM são: reunir as melhores práticas de gestão, ferramentas e conceitos de manufatura e criar a melhor interação e integração possível entre as áreas, as quais são vistas como pilares técnicos, buscando a redução contínua de perdas para alcançar "zero quebras", "zero desperdícios", "zero estoques" e "zero defeitos" por meio de um pensamento enxuto na manufatura. O pensamento enxuto é uma forma de fazer cada vez mais com cada vez menos - menos esforço humano, menos equipamentos, menos tempo e menos espaço (FREITAS; BARROS FILHO, 2016.

\subsection{QUE É WCM E BREVE HISTÓRICO}

O WCM é um modelo de gestão integrada, que pressupõe a melhoria contínua das atividades no âmbito do sistema organizacional. O objetivo é alcançar a competitividade global aderindo aos seguintes princípios: "sem desperdício", "sem estoque", "sem falha", "sem defeito", melhoria de processos aplicados, aumento de produtividade, segurança aprimorada, redução de custos. Baseia-se em três elementos essenciais: combate sistemático a cada desperdício e perda existente; envolvimento das pessoas e respectivos desenvolvimento de suas competências e utilização rigorosa de métodos e ferramentas apropriados para as ineficiências do processo (GONÇALVES; GUIMARÃES; BAGNO, 2014).

A busca por melhor desempenho numa organização é um processo contínuo de aprimoramento em busca da competitividade. WCM foi o termo introduzido para se referir ao objetivo de atingir e / ou sustentar a competitividade de classe mundial por meio da excelência da fabricação.

WCM teve suas origens no Sistema Toyota de Produção (KETTER, 2006). Lean Manufacturing teria surgido ao longo da década de 50 na Toyota. Após uma 
visita à fábrica Rouge da Ford, o maior e mais eficiente complexo fabril do mundo daquela época, os engenheiros da Toyota perceberam uma oportunidade de aperfeiçoar o modelo de produção em massa americano, adequando-o à difícil situação do Japão pós-guerra. Esse novo modelo de produção foi estudado e denominado na década de 80, como Produção Enxuta (WOMACK; JONES; ROOS, 2004).

\subsection{CONSIDERAÇÕES RELEVANTES PARA IMPLEMENTAÇÃO DO WCM}

Organizações em todo o mundo investiram substancialmente quantidades de tempo e dinheiro para WCM. Algumas destas organizações relataram um melhor desempenho, mas também alguns problemas. Uma das possíveis razões para tais problemas pode ser o não reconhecimento da alta gerência da importância dos benefícios da WCM por causa da falta de metodologia de justificação adequada para o investimento financeiro sem as justificativas bem planejadas (SUNNAPWAR; KODALI, 2006).

Os gerentes que pretendem introduzir o WCM em sua empresa devem considerar a necessidade de um bom planejamento e de uma análise de viabilidade financeira (SUNNAPWAR; KODALI, 2006).

A implementação do WCM envolve equipes multidisciplinares e enfatiza a importância da simplicidade na resolução de problemas (KETTER, 2006). A participação de todos os níveis hierárquicos e o investimento em suas competências para que os mesmos possam conhecer os princípios e pilares do WCM são tidos como fundamentais de modo que todo o grupo se adapte às mudanças culturais propostas pela filosofia. Desta forma o investimento em treinamento (em todas as áreas, ao menos para divulgação do WCM) é de grande valia em sua implementação.

Ações inicias precisam estar fundamentadas e bem definidas focadas no valor agregado para seus clientes, sejam eles clientes internos ou externos. Assim cria-se alternativas nos processos e na forma que o mesmo está organizado (LEAN INSTITUTE BRASIL, 2019).

Pettigrew (2003) fez a análise do surgimento dos formatos organizacionais considerados inovadores no enfoque de processos, estruturas e fronteiras. $\mathrm{O}$ autor averiguou que inovações no formato organizacional têm efeitos nos processos de 
mudanças e no aprendizado e que indicadores de desempenho considerado superior é dado numa combinação de mudanças realizadas em conjunto, como: tecnologia, estrutura e estratégia. Atentando-se ao processo de mudança no longo prazo. Pettigrew (2003) destaca que "costumes de aprendizagem mais flexíveis são necessários à medida que as organizações buscam se tornar mais inovadoras nas suas formas e processos". Mudanças de processos contemplam aumento da interação vertical e horizontal, práticas consideradas mais novas de recursos humanos e entrada da tecnologia de informação. Mudanças nos limites da empresa abarcam outsourcing, ou alianças estratégicas.

\subsubsection{Envolvimento e Pessoas}

Wood Jr. (2004) fala que mudança organizacional é "[...] qualquer transformação de natureza estrutural, institucional, estratégica, cultural, tecnológica, humana, ou de qualquer outro componente, capaz de gerar impacto em partes ou no conjunto da organização". Motta (2001) diz que implantar ideias novas depende do preparo inicial de planejar o projeto, despertar a criatividade e inspirar as pessoas e também da habilidade assumir riscos.

Duck (1993) trata a gestão da mudança como administrar a interação entre pessoas que lideram o programa de mudança e pessoas que devem implementar as novas estratégias, aprimorar ou adequar um contexto organizacional propício à mudança, e administrar as relações emocionais essenciais em qualquer transformação.

Aspectos contemporâneos relativos ao entendimento da vantagem competitiva oferecem destaque aos recursos e às dinâmicas internas das organizações como determinantes de níveis superiores de desempenho. Além do mais, indicam novos princípios a serem adicionados a este fórum, sendo um deles a gestão de recursos humanos. "De secundário à explicação do sucesso das empresas, a gestão de pessoas passa a ser vista como uma função fundamental para a geração resultados superiores organizacionais" (MASCARENHAS, 2008, p. 98). Para entender como a vantagem competitiva está relacionada à capacidade de inovar da empresa, é preciso identificar a ligação teórica entre a gestão de pessoas e os processos de inovação.

\subsubsection{Tecnologia da Informação}

Acredita-se que as atuais empresas voltadas para manufatura forneçam consideravelmente um produto de qualidade a menores custos, em um prazo menor. 
Para o atendimento a esses requisitos, os fabricantes estão adequando suas fábricas e processos administrativos, incorporando tecnologias avançadas de sistemas de manufatura, como exemplo a manufatura em célula, sistema de informação de chão-de-fábrica (SFIS), sistema de custeio para atividades se entregas just-in-time (JIT). Para que estas aplicações sejam bem-sucedidas a tecnologia de informação (TI) é fundamental. (Billo et. al 1995).

Frente a estas exigências para se adequar aos processos de WCM um dos grandes desafios é como incluir nesta rotina a área de Tecnologia da informação (TI).

Há uma necessidade, considerada crítica para que os profissionais da área de TI estabeleçam requisitos de informação padrão para aplicação do sistema de manufatura. É necessário que a estruturas de dados tenha um padrão de como operações, procedimentos de configuração, equipamentos, lista de materiais, entre outros requisitos funcionais considerados como básicos para os principais módulos, assim como rastreamento de lote, acompanhamento de produto em produção, tempo de atendimento e controle de estoque e requisitos funcionais são fundamentais para a atualização efetiva (Billo et. al 1995).

Para ser considerado competitivo em WCM, os profissionais de TI, considerados como especialistas, devem desenvolver domínios de pesquisa aplicada emergentes a estrutura de gerenciamento de acordo com as arquiteturas de redes distribuídas e fazer o desenvolvimento de novas ferramentas que utilizem métricas de WCM (Billo et. al 1995).

\subsection{3 Área Financeira}

Os sistemas de controle contábil e gerencial das empresas devem apoiar iniciativas para se tornarem parte do WCM. Apesar disso, os críticos das práticas contábeis tradicionais defendem que os sistemas contábeis modernos não apoiam esses programas para melhoria contínua. (Adler, 1996).

Como os produtos tem seu preço de transferência baseado no custo é recomendado que o custo também incorpore o valor do investimento para adequação da tecnologia de processo, pois é considerado alto, uma vez que estão considerados de maneira competitiva, aconselha-se que os custos envolvidos incluam os custos de oportunidade. Um preço de transferência baseado em custo é impulsionado pelo fato de a tecnologia de processo estar altamente relacionada à vantagem competitiva da empresa (Adler, 1996). 
Para atender as práticas WCM parte do inventário em processo e estoque foram alterados em várias áreas de operação para contrabalançar o tempo de inatividade do equipamento e também para a variabilidade do processo. A parte custos da empresa necessita ser adequados para que o sistema se sustente controlado em questão fiscal e financeira.

\subsection{AS 6 PRÁTICAS - HAYES E WHEELWRIGHT (1984)}

Hayes e Wheelwright (1984) descreveram a manufatura de classe mundial como um conjunto de seis práticas, sugerindo que 0 uso de melhores práticas levaria a um desempenho superior. Eles estavam entre os primeiros autores na área de gerenciamento de operações a abordar a questão das compensações versus sinergias no desempenho da manufatura. Com base no trabalho anterior de Skinner, em 1969, fizeram uma contribuição substancial para este debate, argumentando que era importante ter um conjunto claro de prioridades entre as dimensões do desempenho competitivo, porque era potencialmente perigoso tentar alcançar um desempenho superior em várias dimensões simultaneamente (FLYNN, et. al.,1997).

Prática 1 - Habilidades e capacidades da força de trabalho - Hayes e Wheelwright verificaram que, em relação às firmas na Alemanha e no Japão, as firmas americanas haviam negligenciado habilidades e capacidades da força de trabalho. Eles recomendaram uma postura proativa por parte dos fabricantes dos EUA, concentrando-se em aprendizagens, institutos de formação e acordos de cooperação com institutos técnicos vocacionais.

a) Prática 2 - Gestão da competência técnica - Eles também encontraram na equipe de gestão norte americana a falta de competência técnica, quando comparada ao Japão e à Alemanha, tornando o gerenciamento de fabricação de ponta um desafio significativo. Além de fornecer treinamento técnico para gerentes, eles sugeriram o desenvolvimento de mais gerentes com diplomas de engenharia ou técnicos e a rotatividade de gerentes por meio de funções técnicas em suas organizações.

b) Prática 3 - Competição pela qualidade - Embora Hayes e Wheelwright tenham chamado a terceira prática de competir pela qualidade, sua definição é substancialmente mais restrita do que as definições de gestão da qualidade, concentrando-se principalmente no produto função de 
design, com os clientes como os condutores de qualidade e enfatizaram que o desenvolvimento com a participação dos trabalhadores concentrando-se em mudanças culturais que apoiam a participação dos funcionários.

c) Prática 4 - Participação da força de trabalho - Em termos de participação da força de trabalho, Hayes e Wheelwright enfatizaram que 0 desenvolvimento da verdadeira participação dos trabalhadores deixando os funcionários em equipes, concentrando-se em mudanças culturais e políticas que apoiem a participação envolvimento dos funcionários.

d) Prática $\mathbf{5}$ - Reconstrução da engenharia industrial - A reconstrução da engenharia de manufatura, descreve 0 desenvolvimento interno de equipamentos com características únicas, que é difícil para os concorrentes copiarem. Eles também enfatizaram a importância de desenvolver a capacidade dos funcionários de manter e melhorar seu próprio equipamento, desenvolver o senso de propriedade do equipamento.

e) Prática 6 - Abordagem de melhoria incremental - Sobre abordagens de competitividade, ou abordagens incrementais de melhoria da concorrência. Enquanto as firmas norte-americanas tradicionalmente buscam saltos estratégicos como um meio de melhorar a produção, Hayes e Wheelwright sugerem que os concorrentes de classe mundial buscam a melhoria contínua em pequenos incrementos, vencer a corrida criando um padrão em constante crescimento.

O conceito de WCM foi desenvolvido com base em análises aprofundadas das práticas implementadas por firmas japonesas e alemãs, bem como firmas dos EUA que competiram igualmente com estas. O termo WCM foi usado porque essas firmas estavam associadas a um excelente desempenho em suas indústrias globais, resultando na sua descrição como "classe mundial". Desta forma verificaram que haviam muitos pontos em comum entre essas firmas de grande sucesso, argumentando que a chave para a construção de força competitiva está relacionada a seis práticas de fabricação de classe mundial (HAYES; WHEELWRIGHT,1984). 
Schonberger (1986) propôs 16 princípios da WCM. O princípio 1 se refere aos clientes, ou seja, a importância de juntar-se aos clientes organizando-se por famílias de clientes ou até mesmo por tipo de produto. Isso permite que a empresa compreenda o perfil de seus clientes com base no que eles compram e/ou utilizam.

O princípio 2 também trata dos clientes, porém com o foco na captura de informações, que se bem identificadas e trabalhadas podem permitir que a empresa atue de maneira competitiva na seleção e aplicação de práticas relacionadas a estes clientes. Já o princípio 3 se refere à qualidade, considerando a importância da melhoria contínua, flexibilidade e tempo de resposta. O princípio 4 se refere ao envolvimento dos funcionários da linha de frente em aspectos estratégicos do planejamento da empresa. O princípio 5 trata da redução de alguns fornecedores, bem como de componentes e operações.

Na sequência o princípio 6 aborda a redução dos tempos de fluxo, de setup e de inicialização ao longo da cadeia. O princípio 7 trata de uma proximidade com o cliente considerando taxa de uso ou demanda. Outro princípio relacionado à recursos humanos é o princípio 8, que trata da importância de capacitar continuamente estes recursos considerando aspectos como, por exemplo, rotatividade de função, desenvolvimento de carreira e até mesmo segurança. Ainda com relação à recursos humanos, o princípio 9 se refere ao reconhecimento dos funcionários por meio de recompensas e até mesmo de celebrações para favorecer a contribuição dos mesmos para com a empresa.

Já o princípio 10 trata da necessidade de reduzir ao máximo imprevistos e contratempos, enquanto o princípio 11 retoma às equipes da linha de frente considerando a importância destas equipes conhecerem detalhadamente os processos envolvidos, mantendo registros das informações. O princípio 12 sugere o controle de custo por meio da redução de transações, de relatórios e da simplificação da comunicação. Na sequência o princípio 13 foca no desempenho percebido pelo cliente considerando indicadores como, por exemplo, qualidade, velocidade e flexibilidade.

O princípio 14 sugere a capacitação da equipe de trabalho ao invés da aquisição precoce de novos equipamentos ou até mesmo da automação. Ainda com relação às instalações de trabalho, o princípio 15 recomenda que as mesmas sejam simples, de baixo custo, com flexibilidade de movimentação e que possam atender 
às famílias de produtos e clientes. Por fim, o princípio 16 promove a importância de aumentar a capacidade da organização, favorecendo os demais princípios.

De acordo com Vargas, Vargas e Millán (2017), faltam pesquisas empíricas que mostrem a aplicação destes princípios da WCM como parte de sua melhoria contínua.

\subsection{OS 10 PILARES DE PALUCHA (2012)}

Após uma extensa varredura da literatura com o intuito de identificar as principais aspectos relacionados com sistemas de produção, Palucha (2012) presentou um modelo conhecimento como modelo de dez pilares da World Class Manufacturing (Ver Figura 1).

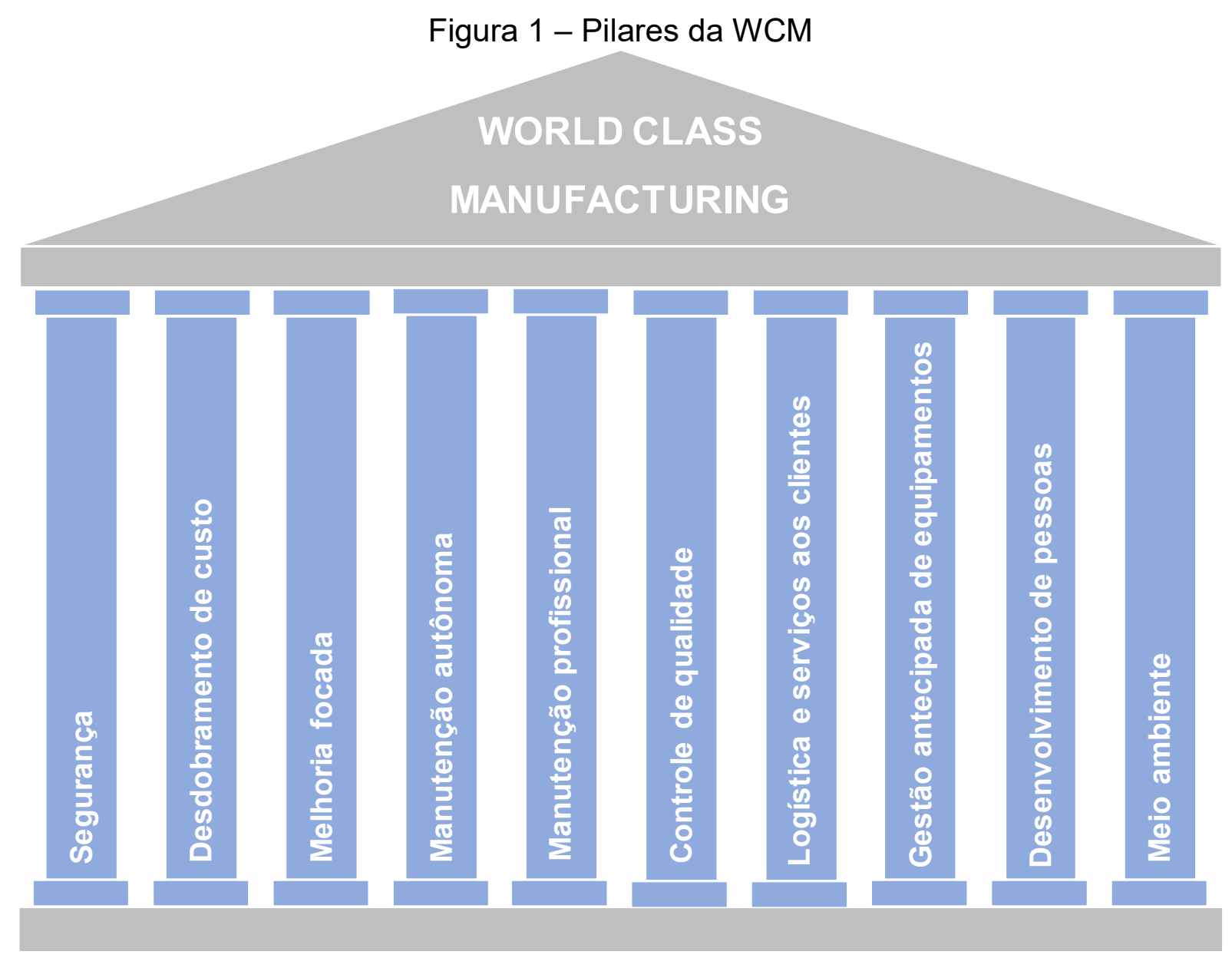

Fonte: Autora "adaptado de" Palucha (2012)

Para Palucha (2012) os dez pilares da WCM são: segurança, desdobramento de custo, melhoria focada, atividades autônomas, manutenção profissional, controle 
de qualidade, logística e serviços a clientes, gestão antecipada de equipamentos, desenvolvimento de pessoas, meio ambiente.

O pilar segurança se refere principalmente à eliminação de acidentes por meio da melhoria contínua e ações preventivas intensas. O pilar desdobramento de custo tem como objetivo analisar detalhadamente as atividades que podem gerar algum tipo de desperdício para que possa ser realizado um plano de ação e, consequentemente melhore o resultado.

O pilar melhoria focada trabalha os principais problemas identificados no pilar de desdobramento de custo. Trata-se de um trabalho minucioso e permanente, com a proposição de ações corretivas que também possam diminuir os desperdícios e até mesmo eliminar alguma atividade que não seja adequada. O pilar manutenção autônomas tem como objetivo principal melhorar a eficiência do sistema produtivo como um todo por meio da preservação e até mesmo restauração de equipamentos, bem como da qualificação dos funcionários responsáveis pela manutenção.

Já o pilar manutenção profissional trata de problemas não solucionados no pilar anterior, ou seja, problemas decorrentes da não identificação de problemas dos equipamentos e até mesmo da não qualificação dos profissionais responsáveis. Um dos objetivos deste pilar é trabalhar em colaboração com os responsáveis pelo pilar manutenção autônoma. O pilar controle de qualidade tem como objetivo que o produto chegue no cliente exatamente conforme o prometido. Trabalha intensamente a identificação de falhas e utiliza técnicas de qualidade para diminuir ao máximo os possíveis defeitos.

O pilar logística e serviços aos clientes foca no fornecimento de condições adequadas de fluxo de materiais dentro da empresa e entre a empresa e seus fornecedores. Isso favorece os resultados de inventário, diminui o deslocamento desnecessário e melhora o resultado financeiro da empresa. O pilar gestão antecipada de equipamentos se refere às atividades que possuem um tempo alto de setup, o que permite a otimização de custos e diminuição de desperdícios.

O pilar desenvolvimento de pessoas foca no treinamento e qualificação de todos os envolvidos na produção. Por fim, o pilar meio ambiente tem como objetivo principal atender aos requisitos ambientais, bem como fortalecer na empresa uma cultura de melhoria contínua. São realizadas auditorias internas, identificação de riscos e prevenção. 
Para atingir a excelência global do modelo é necessário o desenvolvimento simultâneo dos dez pilares, considerando suas respectivas áreas do sistema de produção e suas ferramentas (SARI, 2018). Ainda de acordo com a mesma pesquisa, este modelo tem flexibilidade de aplicação em diversos tipos de empresas que estejam ativas.

É importante levar em consideração a necessidade de preparar os funcionários para que trabalhem neste modelo por meio de equipes onde 0 envolvimento de todos é necessário (MENDES; MATTOS, 2017).

\subsection{QUADRO COMPARATIVO DAS TRÊS REFERÊNCIAS CONCEITUAIS DA WCM}

Nesta seção apresenta-se o quadro $X$ que cruza os componentes das três referências conceituais estudadas - 6 práticas, 16 princípios e 10 pilares, com uma breve discussão sobre similaridades que podem ser destacadas.

Quadro 1- Comparativo das três referências conceituais da WCM

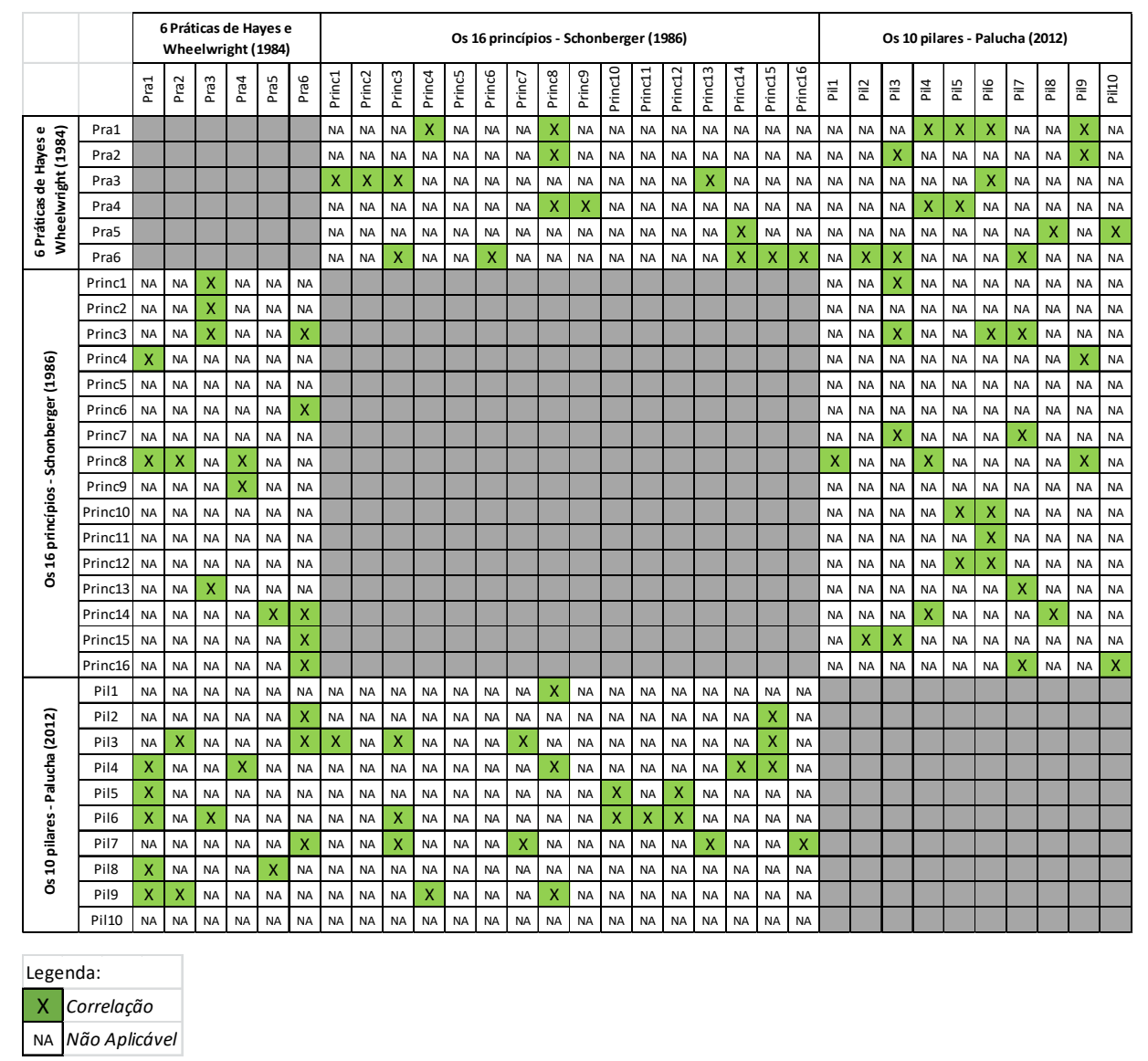

Fonte: Autora 
Pode-se perceber que ao longo do tempo a visão do WCM foi complementada, sem que as práticas iniciais fossem esquecidas ou tornassem obsoletas nas referências estudadas. É possível perceber que ao longo dos estudos as práticas foram incorporadas pelos princípios e posteriormente readequados nos em pilares.

Pode-se observar fortemente a necessidade da capacitação e da participação da força de trabalho, assim como o conceito de qualidade e proximidade com o cliente.

Já a preocupação diretamente relacionada com meio ambiente aparece no estudo dos pilares, mas que pode ser observada indiretamente na prática relacionada a vender as melhorias e reconstrução da engenharia de fabricação, pois atualmente os itens relacionados ao meio ambiente são cobrados pelos clientes na concepção de seus produtos.

Nota-se a adequação dos conceitos relacionados ao WCM como melhoria contínua, uma adequação ao mercado para que as empresas se mantenham competitivas. 


\section{PESQUISA DE CAMPO}

Este capítulo trata da pesquisa de campo realizada. Primeiramente, é apresentado o resultado do estudo bibliométrico realizado, o qual deu suporte ao desenvolvimento teórico e à pesquisa de campo. Em seguida, apresenta-se o método de pesquisa aplicado e as informações sobre como o estudo foi conduzido, bem como as características básicas do objeto de estudo. A terceira e a quarta seções do capítulo referem-se às informações obtidas na pesquisa de campo, sendo que o conteúdo da terceira seção refere-se à apresentação das empresas estudadas, e a quarta seção apresenta os resultados encontrados. Por fim, a quinta e última seção do capítulo apresenta a análise e discussão do estudo.

\subsection{ESTUDO BIBLIOMÉTRICO}

Um trabalho científico tem início com a definição do tema de pesquisa. $O$ ponto de partida é a construção arcabouço teórico (GHAURI; GRONHAUG, 2010). O aumento das publicações ao longo dos anos motivou o uso de técnicas de revisão sistemática da literatura, como por exemplo a bibliometria (LOPES, CARVALHO, 2018; CARVALHO; FLEURY; LOPES, 2013).

A primeira etapa desta pesquisa foi a bibliometria por meio da análise das publicações e das citações. A análise das publicações favorece a compreensão do tema ao longo dos anos (PRASAD; TATA, 2005). Já a análise das citações avança para a relação entre palavras-chave, autores, artigos, periódicos e até mesmo de instituições de ensino (NEELY, 2005).A Figura 2 apresenta o fluxo de trabalho da bibliometria. 
Figura 2 - Fluxo de trabalho da bibliometria
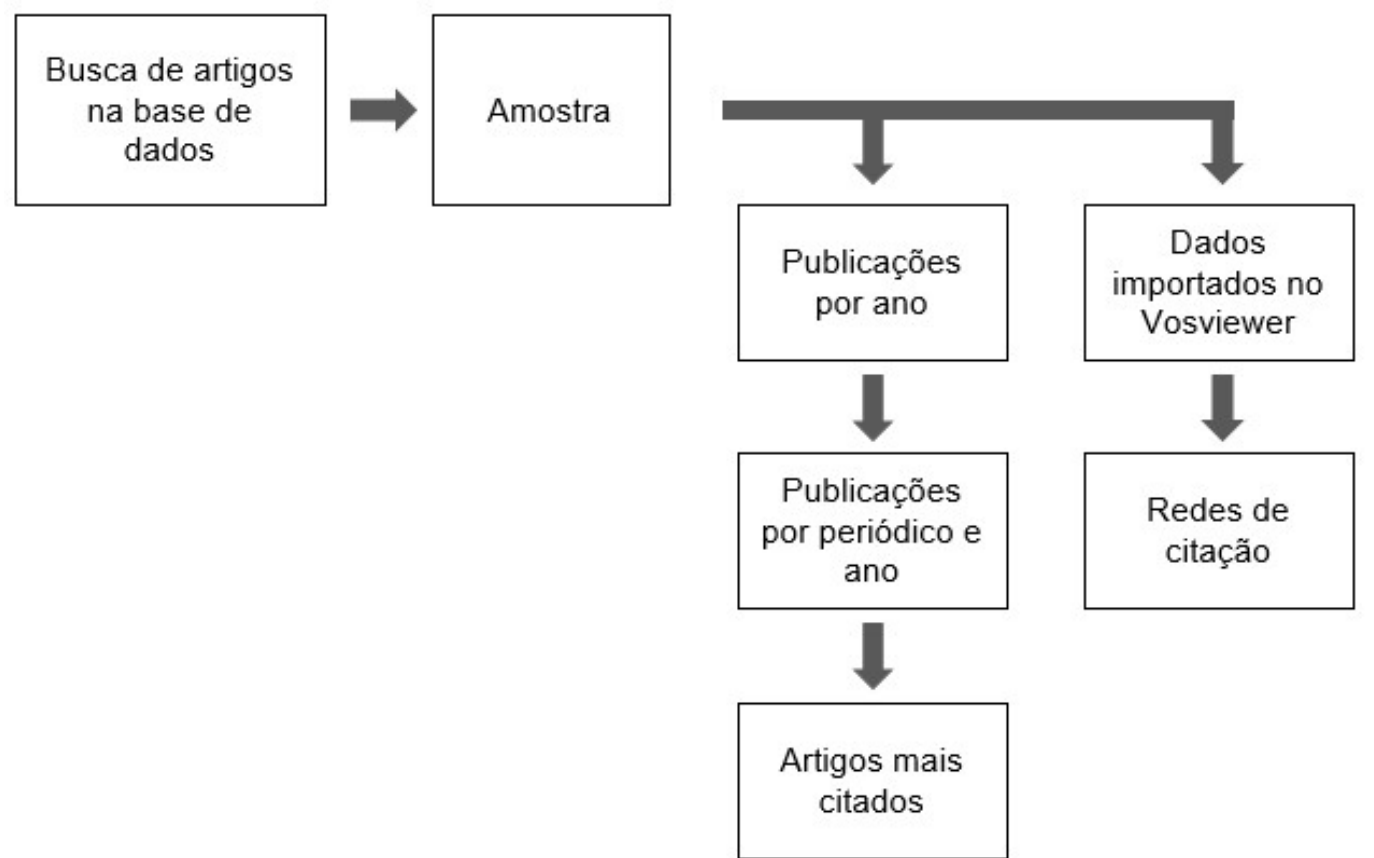

Fonte: Autora

\subsubsection{Análise das publicações}

A base de dados escolhida para a amostra inicial foi a Web of Science e a busca foi realizada em setembro de 2018 com as palavras-chave "world-class manufacturing" or "world class manufacturing" or "WCM" que resultou numa busca de 34 artigos publicados entre 1988 e 2018 (Ver Figura 3)

Figura 3 - Publicações por ano

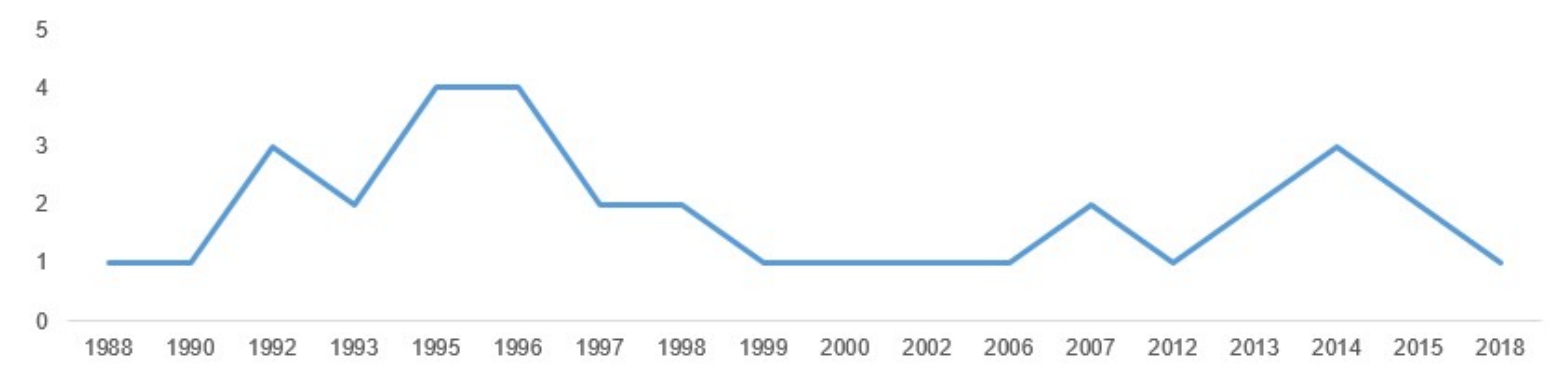

Fonte: Autora

Na Tabela 1 é possível analisar as publicações por periódico e ano. Os periódicos que mais publicaram sobre o tema foram: International Journal of Operations \& Production Management (Journal Citation report $=2,955)$, International 
Journal of Production Research (Journal Citation Report $=2,623$ ), Industrial Engineering (Journal Citation Report $=0,059$ ), Metalurgija (Journal Citation Report = 0,959) e Production Planning \& Control (Journal Citation Report = 2,330).

Já na Tabela 2 é possível verificar os artigos mais citados. Aparecem na tabela os artigos que receberam pelo menos cinco citações. A Figura 4 mostra a evolução destas citações entre 1996 e 2018.

Tabela 1 - Publicações por periódico e ano.

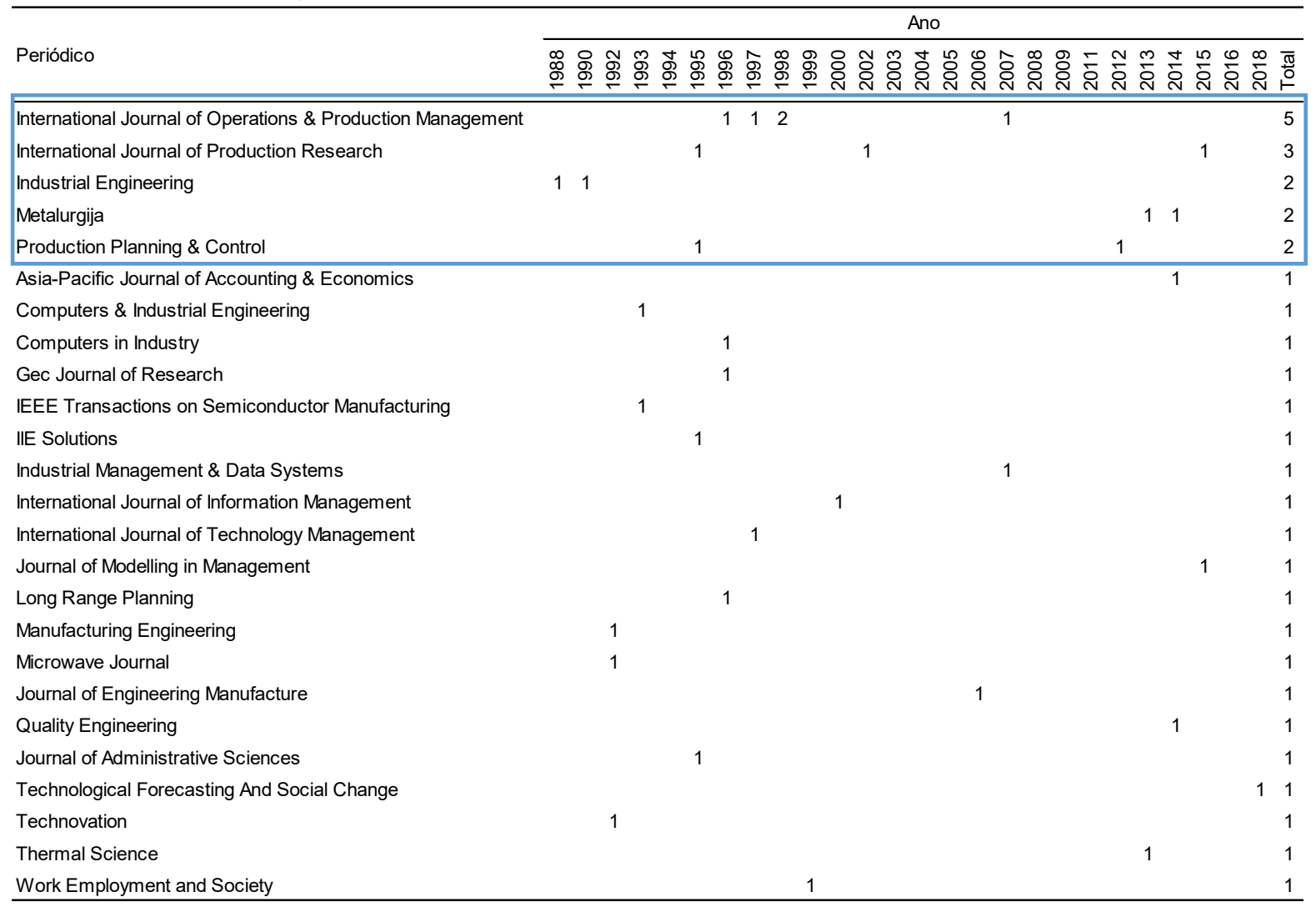

Fonte: Autora 
Tabela 2 - Artigos mais citados

\begin{tabular}{lc}
\hline \multicolumn{1}{c}{ Artigo } & Número de citações \\
\hline Flynn et al. (1997) & 90 \\
Haleem et al. (2012) & 55 \\
Brown, Brian e Blackmon (2007) & 53 \\
Saxena e Sahay (2000) & 32 \\
Voss e Blackmon (1996) & 32 \\
Hendry (1998) & 24 \\
Muda e Hendry (2002) & 16 \\
Harrison (1998) & 16 \\
Lockamy e Cox (1995) & 16 \\
Chiarini e Vagnoni (2015) & 15 \\
Gajdzik (2012) & 15 \\
DeFilippo (1997) & 9 \\
Salaheldin e Eid (2007) & 6 \\
Storey e Harrison (1999) A & 6 \\
Digalwar, Jindal e Sanwan (2015) & 5 \\
Vrakking e Mulders (1992) & 5 \\
\hline
\end{tabular}

Fonte: Autora

Figura 4 - Evolução das citações dos 16 artigos mais citados.

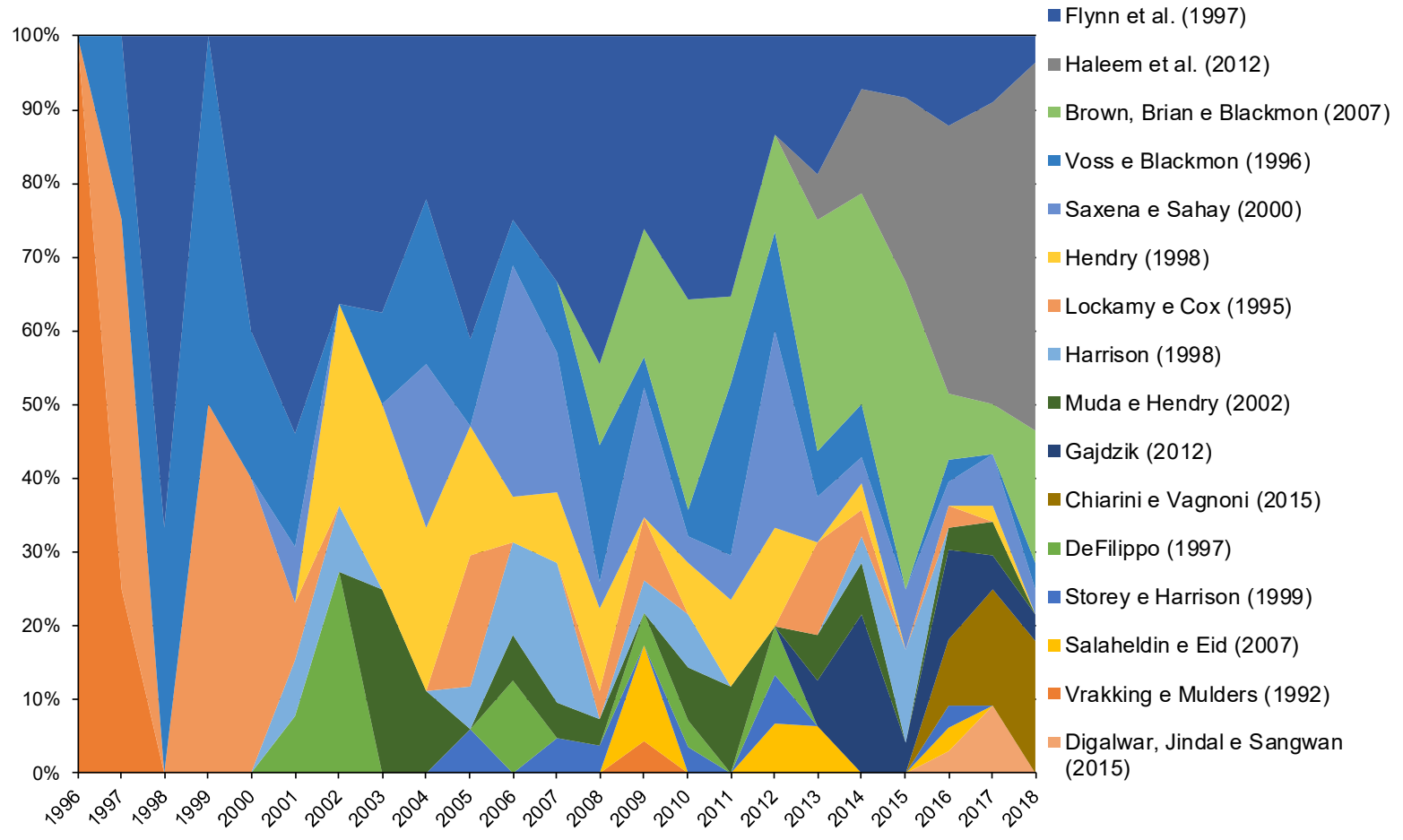

Fonte: Autora 
Entre os anos de 1996 e 2002 foram citados os artigos: Vrakking e Mulders (1992) que pesquisaram a implementação da WCM num contexto de empresas de pequeno porte; Lockamy e Cox (1995) cuja pesquisa analisou sistemas de indicadores de desempenho em empresas com WCM implementada; Voss e Blackmon (1996) que analisaram as práticas da WCM em empresas da GrãBretanha e Alemanha; DeFilippo (1997) que comparou as práticas chinesas de produção com WCM; Flynn et al. (1997) que analisaram publicações relacionadas com WCM desde 1985, quando o termo foi cunhado por Hayes e Wheelwright; Harrison (1998) que analisaram diferentes estratégias de manufatura e as relacionaram com WCM; Saxena e Sahay (2000) que pesquisaram WCM considerando as particularidades nas empresas indianas.

Entre 2003 e 2009 outras quatro pesquisas da amostra começaram a receber citações, sendo elas: Hendry (1998) que analisou WCM considerando o contexto "make-to-order"; Storey e Harrison (1999) que pesquisaram o comportamento no "chão de fábrica" de uma empresa que adotou WCM; Muda e Hendry (2002) que também pesquisaram WCM no contexto "make-to-order"; Brown, Brian e Blackmon (2007) que pesquisaram de que maneira o alinhamento entre WCM e a estratégia de manufatura da empresa pode afetar o resultado.

A partir de 2010 também foram citados: Salaheldin e Eid (2007) que analisaram WCM em empresas egípcias; Gajdzik (2012) que pesquisou WCM em uma empresa metalúrgica; Haleem et al. (2012) que com sua pesquisa identificaram alguns fatores críticos de sucesso das práticas da WCM; Chiarini e Vagnoni (2015) que realizaram uma pesquisa para comparar WCM com o Sistema Toyota de Produção; Digalwar, Jindal e Sangwan (2015) que por meio da utilização do método de equações estruturais numa amostra de dados referentes a WCM identificaram medidas de desempenho.

Importante reforçar a importância do trabalho Flynn et al. (1997) por sua representatividade de área na Figura 4. Trata-se de pesquisa que fez uma importante varredura da literatura desde 1998 e permanece bastante citada ainda hoje. Outra pesquisa bem relevante na Figura 4 é Haleem et al. (2012), que identificou fatores críticos de sucesso, o que também despertou o interesse de outras pesquisas. 


\subsubsection{Análise das citações}

Os dados resultantes da busca feita na base de dados Web of Science foram importados no software Vosviewer com o intuito de analisar as principais redes de citações. A primeira rede é a rede de ocorrência de palavras contidas nos títulos e resumos dos artigos (Ver Figura 5). Esta rede foi analisada considerando a relação entre as palavras ao longo dos anos.

Figura 5 - Rede de ocorrência de palavras

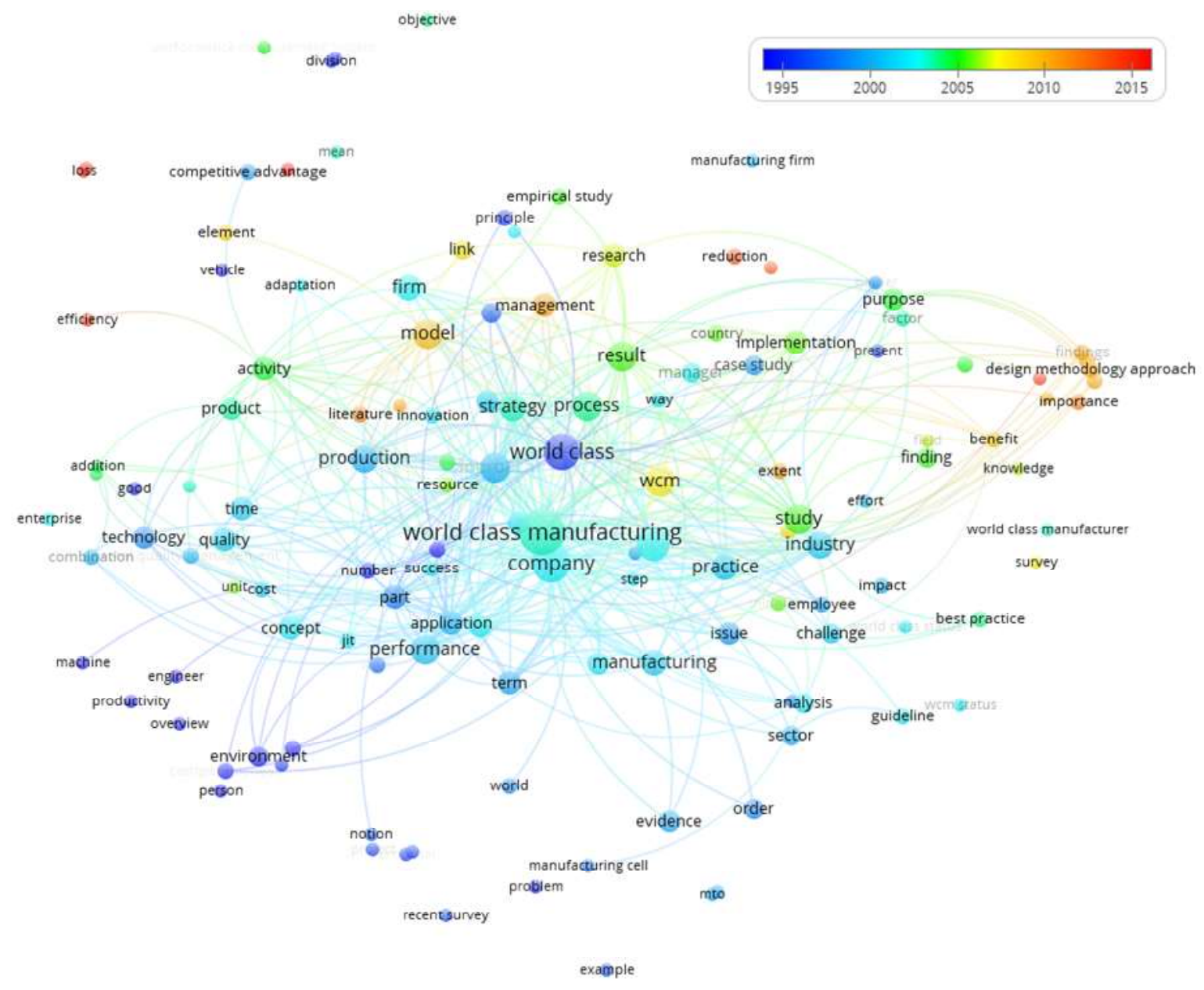

Fonte: Autora

Esta rede mostra que as palavras atuais mais frequentes se referem a uma etapa de avaliação de resultado com relação a WCM, como por exemplo as palavras eficiência, vantagem, perda, redução, etc.

A Figura 6 apresenta a rede de citações (autores). Nota-se um grupo de apenas dois autores, L. Hendry e James DeFilippo, conectados por Linda Hendry à 
um grupo maior de pesquisadores. Na rede em zoom, com mais autores, é possível notar a presença dos autores de quatro dos artigos mais citados, sendo estes artigos Flynn et al. (1997), Harrison (1998), Brown, Brian e Blackmon (2007) e Digalwar, Jindal e Sangwan (2015). Isso reforça a importância destas pesquisas e relevância dos autores.

Figura 6 - Rede de citações de autores

harrison, a

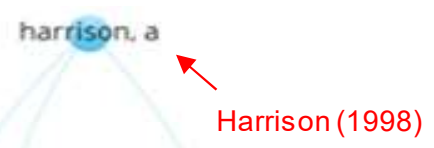

blackmon. $k$

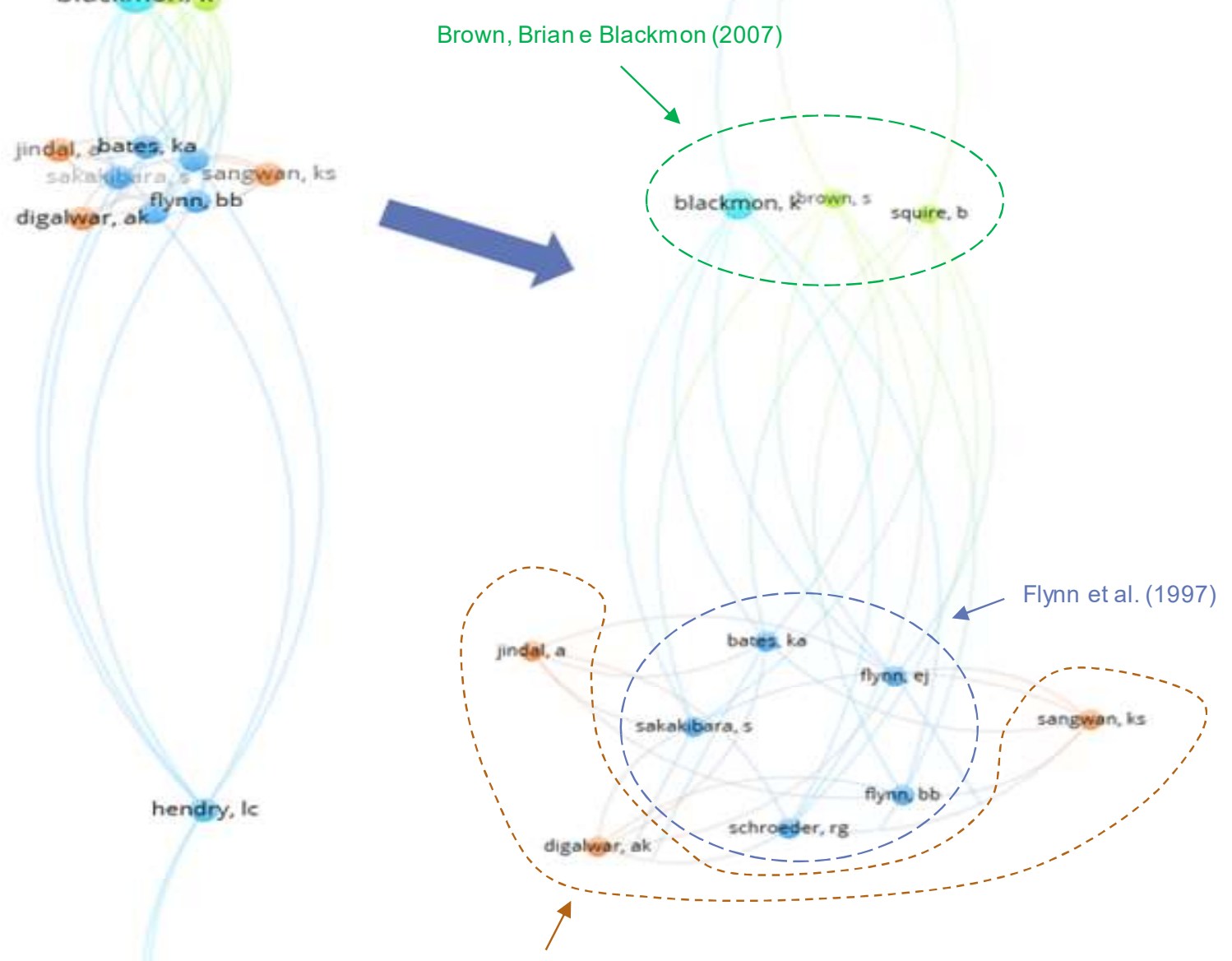

Digalwar etal. (2015)

hendry, I

defilippo, is

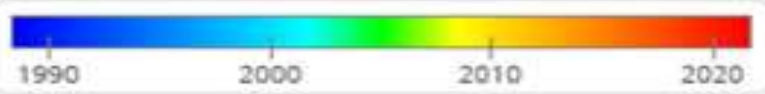

Fonte: Autora 


\subsection{MÉTODO DE PESQUISA}

O método de pesquisa escolhido para a pesquisa de campo foi o estudo de caso, considerando que se pretende responder a perguntas do tipo "como". O estudo de caso pode ser definido como "uma estratégia de pesquisa que visa compreender as dinâmicas presentes em configurações individuais" (EISENHARDT, 1989, p. 534).

Segundo Voss, Tsikriktsis e Frohlich $(2002$, p. 196,197) um estudo de caso envolve as seguintes etapas: "desenvolver o framework de pesquisa, construtos e questões; escolher os casos; desenvolver os instrumentos de pesquisa e protocolos; realizar a pesquisa de campo; documentar e codificar os dados; analisar os dados; desenvolver e testar as hipóteses".

No caso da presente pesquisa, partiu-se da questão de pesquisa e do referencial sobre as práticas, pilares e princípios da WCM para elaborar o roteiro de entrevista (Apêndice A).

A pesquisa foi realizada em uma empresa multinacional que está envolvida com a implantação WCM desde 2010, tendo sido estudadas duas unidades industriais da empresa, chamadas de "empresa A" e "empresa B, cujas características estão indicadas no Quadro 1.

Quadro 1 - Característica da empresa estudada

\begin{tabular}{|l|c|c|}
\hline \multicolumn{1}{|c|}{} & Empresa A & Empresa B \\
\hline Ramo de Atuação & Automotivo & Siderúrgico \\
\hline Início ao WCM & 2010 & 2010 \\
\hline Ano da conquista Bronze WCM & 2015 & Sul Fluminense \\
\hline Localização & Grande São Paulo & Entre 700 - 1000 \\
\hline No de funcionários & Entre 700 - 1000 & Máquinas Centrifugas \\
\hline Área modelo & Fornos Elétricos & Acabamento e metalurgia \\
\hline Áreas de Expansão & Corte e montagem & \\
\hline
\end{tabular}

Fonte: Autora

O programa WCM das duas unidades industriais segue o modelo de referência global da matriz. A próxima seção apresenta o programa geral da empresa, bem como as especificidades das duas unidades industriais pesquisadas. 
Este estudo contou com a participação de colaboradores envolvidos nas rotinas de WCM em dois diferentes níveis, sendo o operacional e o tático, além de análise documental para enriquecer as observações.

O roteiro de entrevista passou por teste piloto para ajustes e adequações, visando a facilitação do entendimento durante as entrevistas e observações.

Nas visitas realizadas nas empresas $A$ e $B$ foi possível conhecer áreas $e$ consultar materiais das unidades produtivas classificadas como áreas modelo, área de expansão, sala dedicada ao WCM, sala para o comitê diretivo.

O direcionamento do programa de WCM é realizado em conjunto com uma consultoria que atende todas as empresas do grupo. A função desta consultoria é levar a padronização dos procedimentos, informações, exemplos de casos bemsucedidos em deferentes fábricas e orientar com relação à auditoria de WCM.

\subsection{DESCRIÇÃO DO PROGRAMA DE WCM NAS EMPRESAS A E B}

As duas unidades industriais fazem parte de um grupo internacional que atua em diferentes segmentos e traz como estratégia central a questão da inovação e obrigatoriedade de ser referência mundial no mercado de atuação.

A empresa $A$ faz parte do segmento automotivo e a planta estudada está localizada na Grande São Paulo. Já a empresa B faz parte do segmento siderúrgico e a planta estudada está localizada no Sul Fluminense.

Ambas têm o programa de WCM como estratégia de manufatura e são classificadas como "bronze" nos mesmos critérios de avaliação (pontuação conquistada em auditorias internacionais realizadas pela matriz do grupo). O modelo global de WCM da empresa classifica cada unidade em três níveis, de acordo com a completude da implementação do modelo referencial (pilares), sendo bronze o terceiro nível, prata o segundo e ouro o primeiro.

A estratégia de Implantação do programa de WCM foi desenvolvida para que a empresa pudesse alcançar o objetivo de atingir e sustentar os indicadores de desempenhos técnicos e financeiros para que, consequentemente, fosse possível manter a competitividade da empresa no mercado e a classificação de empresa de classe mundial por meio da excelência da fabricação, obtida por meio de melhores práticas. 
O histórico da empresa mostra que antes do programa de WCM a empresa já buscava a melhoria contínua com o direcionamento para o lean manufacturing. Porém, para atender a estratégia principal da competitividade o programa lean transformou-se no programa WCM, por estar mais alinhado as metas de desempenho da organização.

O programa de WCM está inserido num programa ainda maior denominado WCSC (World Class Supply Chain) que abrange toda cadeia de abastecimento, sendo a manufatura parte dele. A Figura 7 apresenta o programa de WCM nas empresas estudadas que contemplam os pilares, a fundação e a cobertura do templo.

Figura 7 - Programa de WCM nas empresas A e B

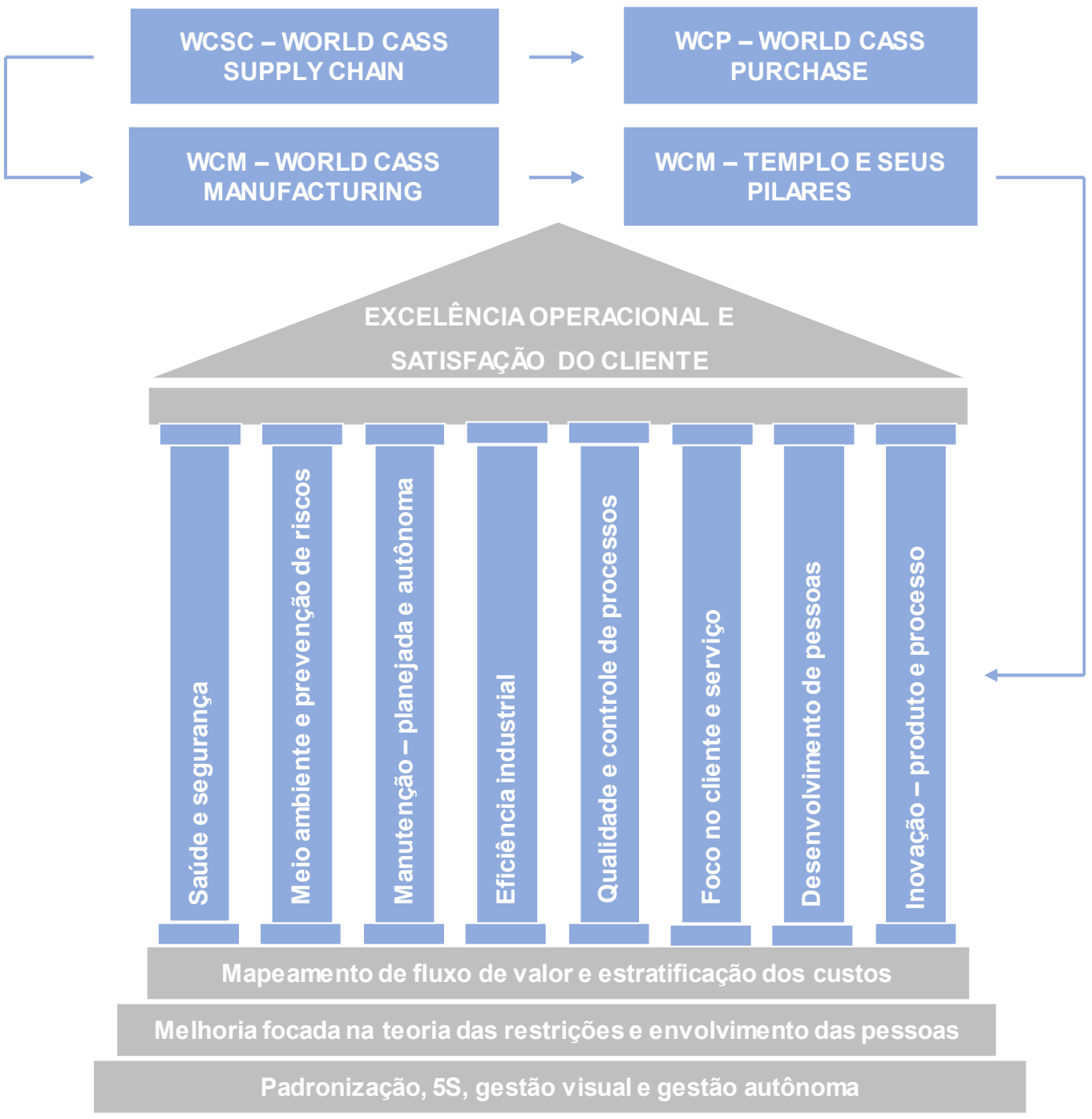

Fonte: Autora 
O WCM, nas empresas estudadas, prevê 8 pilares técnicos, 3 degraus de fundação e a cobertura do templo. Os níveis de realização em campos técnicos são indiretamente afetados pelo nível de realização em campos administrativos. A estrutura dos pilares representa o "Templo do WCM" (Figura 7) e aponta que, para atingir o padrão de excelência, é necessário um desenvolvimento paralelo de todos os pilares. Cada pilar concentra-se em uma área específica do sistema de produção, utilizando ferramentas apropriadas para alcançar a excelência global. O quadro 2 apresenta a descrição dos componentes do "templo do WCM", sendo os três primeiros da "fundação" e os outros dos "pilares".

A Figura 8 apresenta de forma simbólica o Policy Deployment. É um processo de gerenciamento que alinha - vertical e horizontalmente - as funções e atividades de uma organização com seus objetivos estratégicos. Um plano específico nas empresas estudadas foi visto e é realizado anualmente e desenvolvido com metas, ações, cronogramas, responsabilidades e planos de ação. O gerenciamento por objetivos, pode ser observado na Figura 9. Uma vez definidos eles tornam-se um processo de cima para baixo e de baixo para cima, envolvendo um diálogo entre comitê diretivo e equipes de pilares sobre os recursos e tempo disponíveis e necessários para atingir as metas e deve ser verificado no acompanhamento indicadores de desempenho.

Figura 8 - Estrutura do desdobramento da política de WCM nas empresas A e B

\section{Policy Deployment}

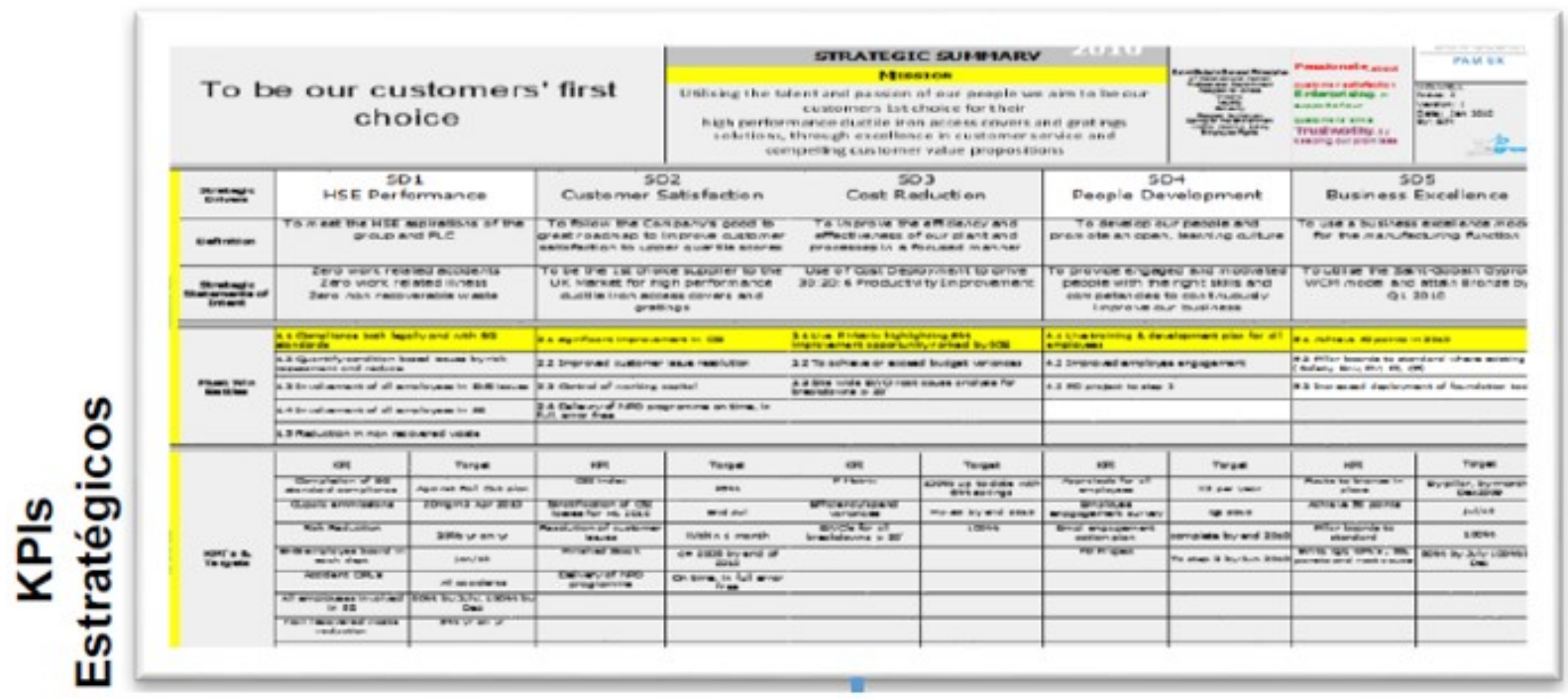

Fonte: Solving Efeso 
Quadro 2 - Descrição dos componentes da fundação e os pilares do templo WCM

\begin{tabular}{|c|c|}
\hline $\begin{array}{l}\text { Descrição do pilarl } \\
\text { fundação }\end{array}$ & Objetivo e características dos pilares e degraus da fundação \\
\hline $\begin{array}{l}\text { Padronização, } 5 \text { S, } \\
\text { Gestão Visual e } \\
\text { Autonomia }\end{array}$ & $\begin{array}{l}\text { Alcançar a excelência através da melhoria do local de trabalho em termos de ordem, organização e } \\
\text { limpeza. A técnica é baseada em: Seiri (separado e ordem); Seiton (organizar e organizar); Seiso } \\
\text { (limpo); Seiketsu (padronizado); Shitsuke (mantendo e melhorando). }\end{array}$ \\
\hline $\begin{array}{l}\text { Melhoria focada e } \\
\text { envolvimento de } \\
\text { pessoas }\end{array}$ & $\begin{array}{l}\text { Melhoria focada na Teoria é um conjunto de atividades destinadas a elevar o desempenho, } \\
\text { especialmente um sistema de manufatura, com relação ao seu objetivo, perdas. Para alcançar este } \\
\text { objetivo conta com a participação de todos os colaboradores, também chamado de envolvimento de } \\
\text { pessoas. }\end{array}$ \\
\hline \multirow{5}{*}{$\begin{array}{l}\text { Mapeamento do fluxo de } \\
\text { valor e estratificação dos } \\
\text { custos }\end{array}$} & Identificar as perdas mais importantes presentes na fábrica do sistema, eliminando ineficiências. \\
\hline & Identificar sistematicamente os principais itens de perda no negócio de produção-logística do sistema. \\
\hline & Quantificar os potenciais benefícios econômicos e esperados. \\
\hline & Abordar os recursos e o comprometimento com tarefas gerenciais com maior potencial. \\
\hline & $\begin{array}{l}\text { Destacar o desperdício de um negócio de processos, ajudando a representar o fluxo atual de materiais e } \\
\text { informações que, em relação a um produto especíico, através do fluxo de valor entre cliente e } \\
\text { fornecedores. }\end{array}$ \\
\hline \multirow{3}{*}{ Saúde e Segurança } & Reduzir significativamente o número de acidentes. \\
\hline & Desenvolver uma cultura de prevenção. \\
\hline & Melhorar a ergonomia do local de trabalho. \\
\hline \multirow{3}{*}{$\begin{array}{l}\text { Meio Ambiente e } \\
\text { prevenção de Riscos }\end{array}$} & Atender aos requisitos e padrões de gestão ambiental. \\
\hline & Desenvolver uma cultura energética e reduzir os custos e perdas de energia. \\
\hline & Reduzir potenciais de riscos associados as atividades rotineiras. \\
\hline \multirow{4}{*}{$\begin{array}{l}\text { Manutenção Planejada e } \\
\text { Autônoma }\end{array}$} & $\begin{array}{l}\text { Melhorar a eficiência geral do sistema de produção através de políticas de manutenção através dos } \\
\text { operadores. }\end{array}$ \\
\hline & $\begin{array}{l}\text { Organização do Local de Trabalho para determinar uma melhoria no local de trabalho, porque muitas } \\
\text { vezes os materiais e equipamentos são degradados; porque no processo há muitas perdas. }\end{array}$ \\
\hline & Aumentar a eficiência das máquinas usando técnicas de análise de falhas. \\
\hline & $\begin{array}{l}\text { Facilitar a cooperação entre operadores e mantenedores (pessoal de manutenção) para atingir } \\
\text { desarranjos zero. }\end{array}$ \\
\hline \multirow[t]{2}{*}{ Eficiência Industrial } & $\begin{array}{l}\text { Reduzir drasticamente as perdas mais importantes presentes na fábrica do sistema, eliminando } \\
\text { ineficiências. }\end{array}$ \\
\hline & Eliminar as atividades sem valor agregado, a fim de aumentar a competitividade do custo do produto. \\
\hline \multirow{3}{*}{$\begin{array}{l}\text { Qualidade e Controle de } \\
\text { Processos }\end{array}$} & Para garantir processo estável. \\
\hline & Para garantir produtos de qualidade. \\
\hline & Para reduzir a não conformidade. \\
\hline \multirow{3}{*}{$\begin{array}{l}\text { Foco no cliente e } \\
\text { Serviço }\end{array}$} & Reduzir significativamente os níveis de estoques. \\
\hline & Aumentar a satisfação do cliente. \\
\hline & Minimizar o manuseio do material, e movimentação. \\
\hline \multirow{4}{*}{$\begin{array}{l}\text { Desenvolvimento de } \\
\text { Pessoas }\end{array}$} & Desenvolver competências profissionais específicas de resolução de problemas. \\
\hline & Aumentar as habilidades dos funcionários. \\
\hline & $\begin{array}{l}\text { Garantir, através de um sistema estruturado de treinamento, habilidades e habilidades corretas para } \\
\text { cada estação de trabalho. }\end{array}$ \\
\hline & $\begin{array}{l}\text { Desenvolver as regras de trabalhadores de manutenção, tecnólogos, especialistas, como treinamentos } \\
\text { específicos considerados estratégicos para diferencial da empresa. }\end{array}$ \\
\hline \multirow{5}{*}{$\begin{array}{l}\text { Inovação de processos e } \\
\text { produtos }\end{array}$} & Colocar em funcionamento novos equipamentos nas plantas conforme programado. \\
\hline & Garantir um arranque rápido e estável. \\
\hline & Reduzir o custo do ciclo de vida. \\
\hline & Desenvolver novos produtos \\
\hline & Para projetar sistemas facilmente mantidos e inspecionados. \\
\hline
\end{tabular}

Fonte: Autora 
Figura 9 - Gerenciamento dos Indicadores de desempenho na política de WCM nas empresas A e B

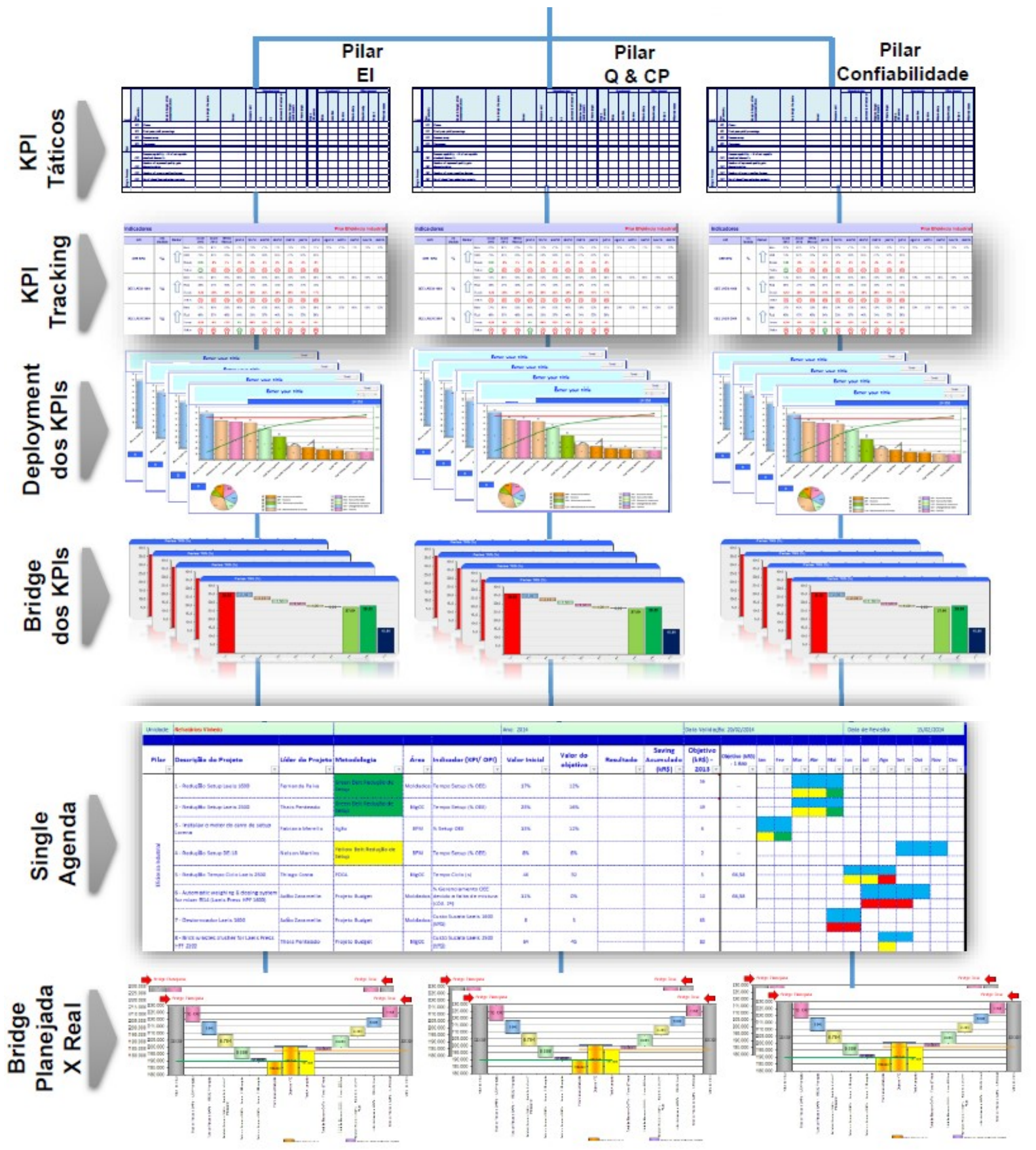

Fonte: Solving Efeso

A analogia com estrutura de templo é uma forma de ilustrar e facilitar a fixação da ideia de uma forte fundação para sustentar os pilares, os quais suportam a cobertura do templo, que é o objetivo maior. Além dos pilares há um desdobramento que faz o programa de WCM ser maior e alcançar todos os colaboradores. 
A fundação é considerada essencial e comum para todos os pilares, sendo composta por níveis, onde pode ser verificada a importância da padronização, dos $5 S$, da gestão visual e da gestão autônoma em seu primeiro nível. No segundo nível da fundação tem-se a melhoria focada na teoria das restrições, que se trata de um conjunto de atividades destinadas a elevar o desempenho do sistema, especialmente um sistema de negócios, com relação ao seu objetivo e o envolvimento das pessoas, pois sem a participação de toda a estrutura o programa torna-se frágil.

Em seu terceiro nível, que serve como direcionador para os pilares, tem-se o mapeamento do fluxo de valor, que serve para analisar o estado atual e projetar um estado futuro para uma série de eventos que envolvem desde o desenvolvimento de um produto e/ou serviço até a etapa de redução de desperdícios, em comparação com o mapa atual e a estratificação dos custos, pois a orientação é direcionar os pilares na tratativa das principais perdas financeiras.

Continuando na estrutura do modelo, tem-se os pilares, que são oito: saúde e segurança; meio ambiente e prevenção de riscos; manutenção planejada e autônoma; eficiência industrial; qualidade e controle de processos; foco no cliente e serviço; desenvolvimento de pessoas, e inovação de processos e produtos.

As empresas lançam os pilares (iniciam as atividades) conforme as orientações das informações provindas das ações realizadas nos níveis da fundação. As duas empresas estudadas apresentam como pilar prioritário o pilar saúde e segurança. Assim, os pilares subsequentes são lançados conforme a necessidade das empresas já sinalizadas pelas atividades realizadas no contexto dos níveis da fundação.

A empresa A também apresenta como pilares de alta prioridade eficiência industrial e manutenção planejada e autônoma, pois suas perdas tem as tratativas das ferramentas destes pilares. Após ativar estes três pilares prioritários, sucessivamente foram lançados os seguintes pilares: meio ambiente e prevenção de riscos; qualidade e controle de processos; foco no cliente e serviço; desenvolvimento de pessoas. Na última fase antes das auditorias e de forma embrionária, iniciaram-se as atividades do pilar inovação de processos e produtos, pois este recebe a demanda dos demais pilares.

A empresa $B$, após o pilar saúde e segurança, apresentou como pilares de alta prioridade manutenção planejada e autônoma e qualidade e controle de 
processos, pois suas perdas identificadas tem as tratativas das ferramentas destes pilares. Na sequência, foram ativados os pilares meio ambiente e prevenção de riscos; eficiência industrial; foco no cliente e serviço; desenvolvimento de pessoas. Após o desenvolvimento dos pilares citados, na última fase antes das auditorias e de forma embrionária, assim como na empresa $A$, iniciaram-se as atividades no pilar inovação de processos e produtos, pois este recebe a demanda dos demais pilares.

Foi percebido nas duas empresas que o pilar de inovação inicia suas atividades voltado para inovação dos processos antes de atuar na inovação do produto. O que foi dito em ambas as empresas é que o nível de qualidade dos produtos ainda não alcançou o objetivo de excelência e por este motivo os processos passam por adequação. Após a adequação dos processos produtivos há uma dedicação na estruturação do pilar para inovação no desenvolvimento de produtos. A Figura 10 ilustra de forma resumida o que o WCM espera com o desenvolvimento do programa ao longo do tempo.

Figura 10 - O que se espera do Programa de WCM nas empresas A e B

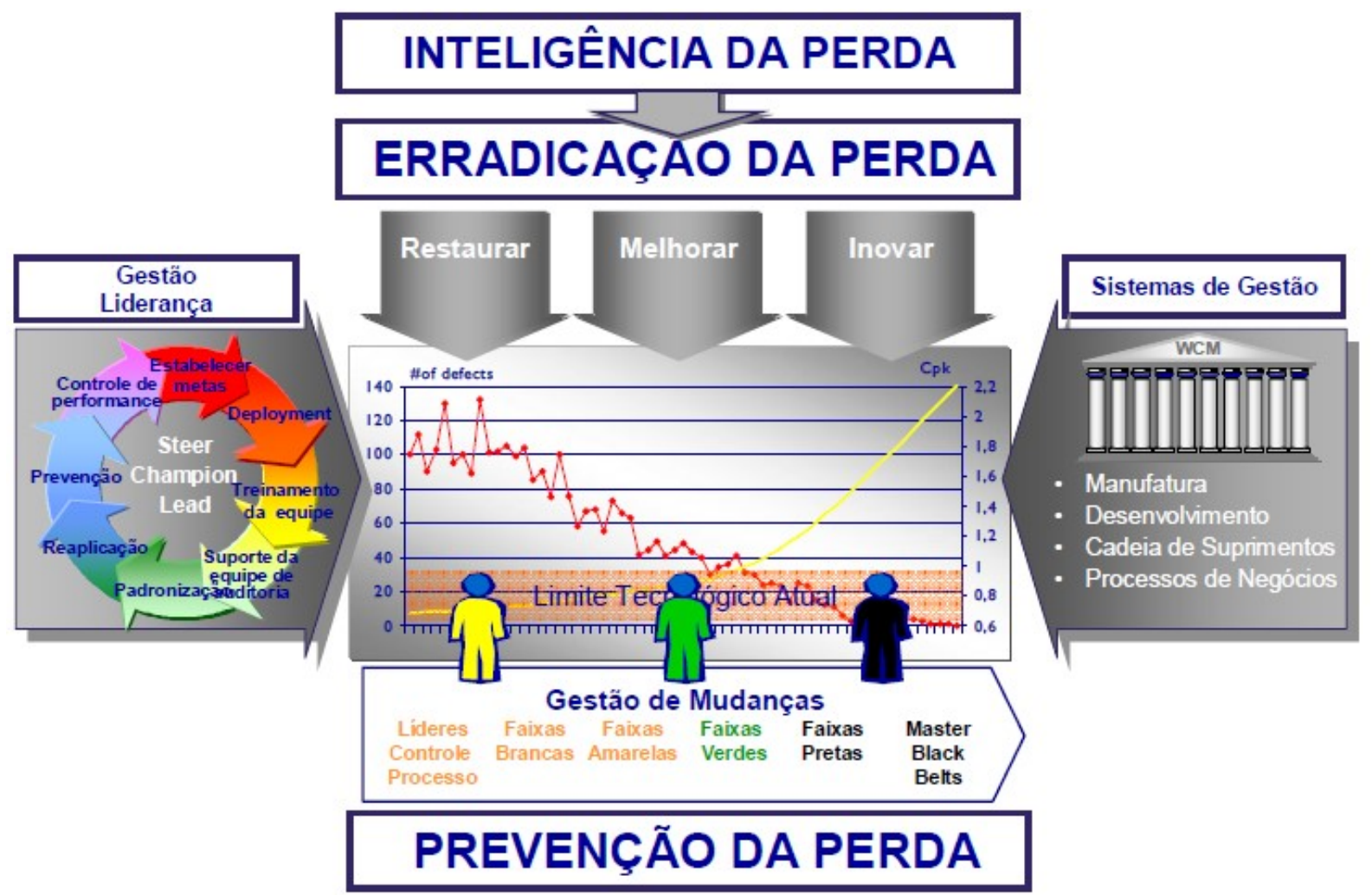

Fonte: Solving Efeso 
A prática da gestão dos pilares é fundamental para alcançar o objetivo proposto pelo programa WCM. A implementação do programa WCM nas duas empresas reforça o objetivo de se manterem competitivas, principalmente com a atuação dos pilares técnicos fundamentados por estudos de estratificação dos custos. Para isso ocorre o envolvimento das equipes técnicas (manufatura e relacionados diretos) com as equipes do financeiro ou controladoria.

O WCM se desdobra ao redor dos cinco níveis de KPI (Key Performance Indicator - Indicador-chave de desempenho) apresentados nas duas empresas (Ver Figura 11). É a forma que se tem de gerir os pilares de forma simplificada e objetiva. Dentro destes cinco níveis existem as rotinas WCM.

Figura $11-5$ níveis do KPI

\section{Definir os indicadores (KPI e OPI) - Desdobramento da política}

\section{Identificar as principais perdas (Pareto) - Cada KPI deve ser estratificado}

\section{Planejar melhorias - Após a identificação das perdas as iniciativas devem ser inseridas na single agenda e no gráfico de ponte}

\section{Realização das iniciativas de melhoria com foco atingimento do objetivo principal do projeto}

\section{Após a conclusão do projeto os resultados devem ser atualizados na single} agenda e nas bridges e as auditorias nas áreas produtivas devem ser realizadas com frequência pré-estabelecida, para que os ganhos alcançados se sustentem

Fonte: Autora

Os pilares têm suas diretrizes para tratativas das perdas específicas e direcionadas pelos seus indicadores de desempenho. Quando se percebe que há alguma perda relacionada a algum indicador, porém a ferramenta da tratativa está em outro pilar, então é feita a demanda para o pilar responsável pela atuação na mesma. Desta forma, para ambas as empresas foi observado o uso comum de algumas ferramentas: single agenda, uma agenda única que contempla todas as 
iniciativas para tratativas das perdas; gráficos de ponte, denominados de bridges, onde pode-se verificar o indicador na situação atual e na situação desejada, e então são listadas as iniciativas com o percentual de ganho esperado, tanto técnico como financeiro.

Figura 12 - Exemplificação do gráfico de ponte

Produtividade (\%)

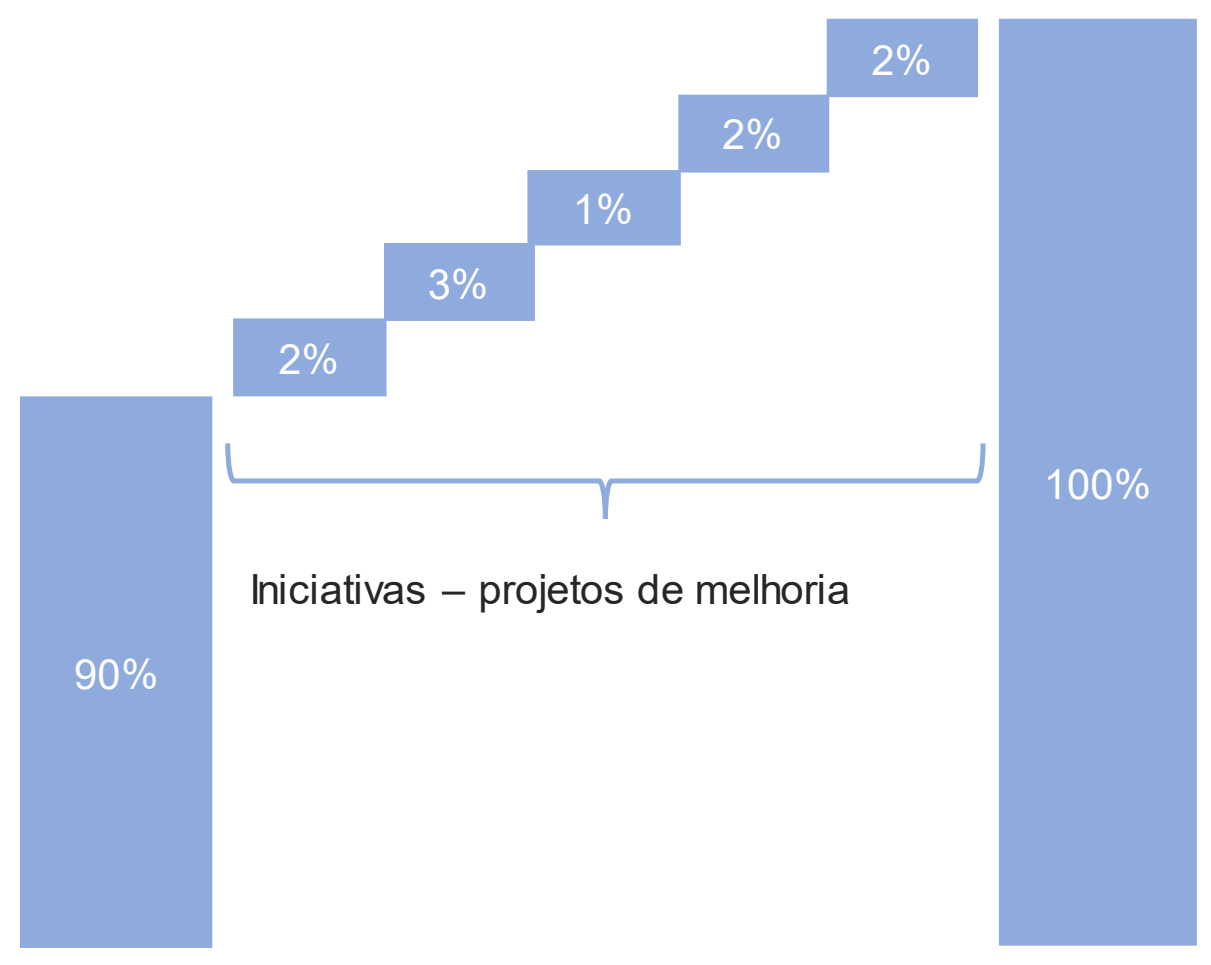

Fonte: Autora

As iniciativas de melhoria geralmente são realizadas por grupos de trabalho denominados black, green ou yellow belts, que são os grupos de melhorias (faixas preta, verde e amarela). Esta classificação é dada conforme a complexidade do problema apresentado. Dependendo do grau de dificuldade recomenda-se a ferramenta standard kaizen, que é o formulário de kaizen padrão.

Obrigatoriamente, todos os grupos de melhoria devem: ter entre os membros pessoas da área produtiva; consultar a visão do cliente para possíveis impactos, sejam estes clientes internos ou externos; desenvolver padronização; considerar possíveis impactos em outras áreas periféricas ao projeto (exemplos: segurança, lead time, tempo de setup). 
Todas as iniciativas são tratadas de forma técnica e financeira. Logo cada indicador tem dois gráficos de ponte, um sendo o desenvolvimento do indicador de desempenho técnico e o outro o de desempenho financeiro. Estes gráficos devem ser atualizados de forma espelhada, refletindo o planejado versus o realizado, para verificar se o que está sendo feito realmente está atendendo o que foi previsto. Pode-se verificar um exemplo de gráfico de ponte espelhado na Figura 13.

Figura 13 - Exemplo de gráfico de ponte espelhado

Produtividade (\%)

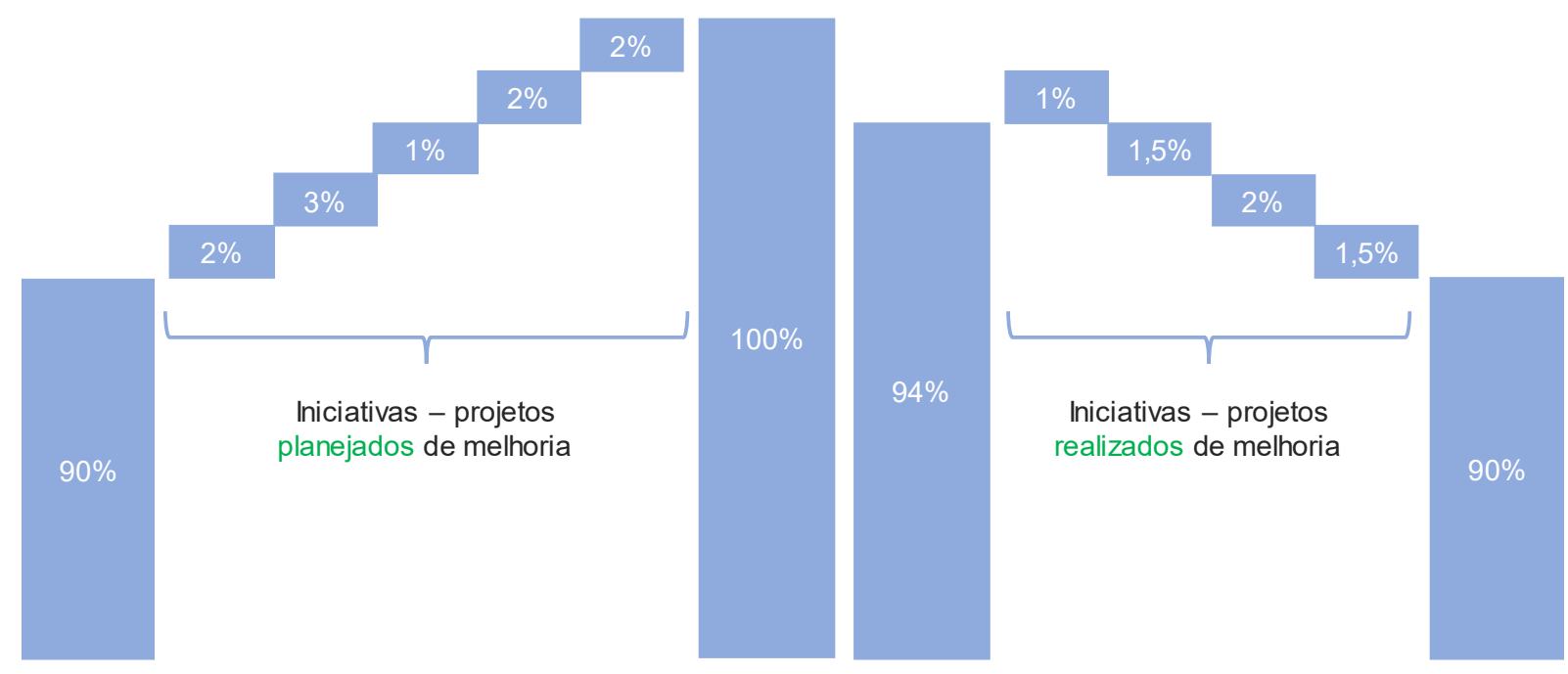

Fonte: Autora

Foi observado nas duas empresas que a participação das equipes financeiras ou de controladoria é de suma importância para a validação das inciativas de WCM. Também foi relatada nas duas empresas a dificuldade na integração entre as equipes financeira e de manufatura. Não há o envolvimento das equipes financeiras no planejamento de ganhos, porém é obrigatória a presença desta equipe para a validação dos ganhos reais.

As práticas de gestão para os pilares é a mesma, independente da área de atuação. De fato, isso é esperado pois a gestão do programa WCM é sistêmica e padronizada. O programa de WCM é avaliado em auditorias por um GRID, que é um caderno para orientação durante a auditoria de WCM contemplando cada critério que deverá ser atendido. Este caderno é elaborado e atualizado por uma equipe multifuncional e internacional que considera as práticas comuns para se obter melhores resultados. Este GRID pode ser considerado como um caderno que 
contempla 19 abrange todos dos pilares, fundação e também inclui itens estratégicos para o negócio como visão, compromissos de gestão, planejamento, entre outros.

Pode-se dizer que o GRID contempla todas as diretrizes do WCM nas empresas estudadas, o que vai ao encontro das práticas, princípios e pilares estudados com as particularidades dos casos estudados.

\subsection{RESULTADOS}

Foi percebido que com o passar dos anos os estudos sobre WCM foram sendo aprimorados e o modelo de WCM foi reestruturado para atender as demandas das empresas contemporâneas. A tendência mostra que para que uma implementação seja considerada alinhada ao modelo WCM, a flexibilidade e as adaptações devem estar presentes. Principalmente por motivos de competitividade, precisa adequar-se às exigências dos mercados e do ambiente social e político em sua área de atuação (FREITAS; BARROS FILHO, 2016).

No estudo realizado, tem-se um exemplo que mostra a orientação padrão geral e a particularidade de cada empresa. Foi o evento de semana de WCM que é padrão para todas as unidades do grupo, porém o conteúdo é livre para cada empresa.

A empresa A apresentou os seguintes materiais referente a semana de WCM: maior número de atividades interativas como teatro (com a participação dos colaboradores), paródias musicais e jogos. A empresa B apresentou relatos e materiais com atividades mais formais como palestras, visitas técnicas em áreas e alguns jogos sobre WCM.

$\mathrm{Na}$ abordagem das atividades de rotina de WCM realizada nas visitas e entrevistas foi observada a questão do regime de turnos, que são diferentes entre as empresas $A$ e $B$. Empresa $A$ tem regime de 3 turnos fixos, já a empresa $B$ tem regime de 3 turnos rotativos.

Para as atividades de rotina do WCM o regime de turno impacta na participação dos colaboradores. Na empresa A os colaboradores do terceiro turno (22:00-6:00h) relataram não participarem de muitas atividades relacionadas ao WCM quando comparados aos colegas dos outros turnos. A participação das equipes do terceiro tuno nas atividades de WCM se resumem no preenchimento de um quadro 
com os resultados hora a hora e semana de WCM. Já na empresa B os colaboradores relatam ter a mesma chance de participação das atividades da semana WCM, uma vez que cada evento é realizado em um horário diferente.

Foi observado que são os mesmos colaboradores que são membros dos diferentes pilares, quando verificadas as equipes nos documentos de responsabilidades dos pilhares apresentado nas duas empresas. Isso de fato foi relatado como uma queixa comum nas empresas estudadas e deixado como observação de auditorias de WCM quando observado nos relatórios como oportunidades de melhorias.

Durante as entrevistas foi possível perceber nas duas empresas o mesmo padrão de dificuldades quanto ao alinhamento da rotina do WCM (nível tático) com a rotina que a função do funcionário exige. Vale a pena comentar que as práticas do WCM deveriam ser incorporadas nas atividades da rotina operacional, porém não há a percepção desta integração. Quando os coordenadores do programa foram consultados sobre este ponto, ambos apresentaram evidências práticas de que 0 que as pessoas dizem está relacionado às questões culturais ou à resistência com relação as mudanças, o que leva as pessoas a preferirem fazer as atividades separadamente, levando inclusive a algumas situações de duplicação de atividades.

$\mathrm{Na}$ empresa $\mathrm{A}$, quando questionados sobre as ferramentas utilizadas, os operadores destacaram o formulário de "quick kaizen", que é um formulário cujo objetivo é permitir analisar rapidamente e de forma simplificada a causa de um problema que ocorreu durante o turno. Também indicaram os "tabelões de máquina hora-hora" que podem ser encontrados ao lado dos postos de trabalho com a marcação dos principais indicadores de desempenho, problemas e as ações tomadas para tratar os desvios.

$\mathrm{Na}$ empresa $\mathrm{B}$, quando questionados sobre as ferramentas utilizadas, os operadores destacaram o formulário de "quick kaizen" e a "etiqueta de gestão autônoma", que busca trazer melhoria para o processo por meio de uma sugestão. Além disso, foi relatada a prática de reunião de final de turno, e apresentado o quadro com as anotações do resultado. Foi possível observar os quadros preenchidos nas áreas, porém nenhum operador relatou o preenchimento destes quadros de forma associada ao WCM.

Na comparação entre a empresa A e B, foi possível verificar a presença dos "tabelões de máquina hora-hora" e do formulário "quick kaizen", pois a sistemática 
do programa prevê estes itens. Porém, a forma de envolvimento dos colaboradores é diferente. Na empresa A a postura dos colaboradores é mais corretiva frente aos desvios observados nos indicadores de desempenho. Já na empresa B, a postura é voltada para iniciativa de melhorias na área e no processo.

Com relação aos indicadores, foi questionado sobre quais os indicadores são comuns para as pessoas consultadas. Na empresa $A$, as respostas da equipe do nível operacional apontaram para OPI (Operational Performance Indicators Indicadores de Desempenho Operacional) que puderam ser vistos nos tabelões de máquina hora-hora. As equipes consideradas de nível tático mostraram os indicadores OPI nos tabelões de máquina hora-hora, e também os KPI. Alguns envolvidos nos pilares também apresentaram o link entre os indicadores dos pilares e indicadores dos tabelões de máquina hora-hora. Os indicadores operacionais mais comentados e mostrados foram: cadência; número de peças boas; tempo e número de parada de máquina por quebra. Já os indicadores citados pelos participantes do nível diretivo foram: OEE (Overall Equipment Effectiveness - Eficiência Global do Equipamento); Custo de parada, OTIF (On-Time-In-Full - entrega para o cliente no prazo e na quantidade solicitada).

Na empresa B, o resultado foi similar, mas ao invés de tabelões de máquina hora-hora foram mostrados os tabelões de troca de turno, onde estão os indicadores de OPI. No nível tático, foi a mesma linha de resposta indicando que estas funções fazem treinamento com os colegas de outras unidades de diferentes negócios para que as apresentações e gestão dos resultados sejam o mais similar possível, respeitando as particularidades do processo. Os indicadores operacionais mais comentados e mostrados foram: cadência; temperatura do metal; tempo de parada de máquina por quebra e paradas operativas. Já os indicadores citados pelos participantes do nível diretivo foram: OEE (Overall Equipment Effectiveness Eficiência Global do Equipamento); "em curso" (indicador que mede quanto da produção ainda não foi entregue ao cliente final) e consumo de materiais operativos.

Fazendo uma análise documental nas duas empresas, foi possível relacionar os indicadores mais citados com a estratificação dos pilares, o que mostra uma boa aderência ao desdobramento dos indicadores prioritários. Para o nível de gestão os treinamentos são realizados em outras plantas similares ao redor do mundo para adquirem além da formação técnica o benchmark. 
Quanto aos benéficos de WCM na rotina, as equipes operativas da empresa A indicaram o envolvimento e o treinamento da mão-de-obra, onde os gaps apresentados na matriz de competência têm sido tratados. Assim, eles sentem-se mais bem preparados para atuação frente aos desvios na operação. Os treinamentos relacionados aos critérios dos clientes foram os que os envolvidos tiveram maior satisfação em participar. $\mathrm{Na}$ empresa $\mathrm{B}$, as equipes viram benefícios na limpeza, organização das áreas produtivas e gestão visual. Trouxeram o envolvimento como uma parte relevante, onde exemplificaram que mensamente há dois importantes eventos, o seminário de segurança e o encontro operacional, que traz os resultados dos indicadores do mês e sempre aborda itens conceituais.

Já as equipes táticas de ambas as empresas relataram treinamentos específicos de WCM voltados para a preparação prévia para auditorias, que os deixam mais bem preparados para o momento das auditorias. As equipes operacionais da empresa A entendem que a dificuldade que o WCM trouxe em suas atividades é a quantidade de itens a serem preenchidos em quadros e a participação em grupos de melhorias quando se trabalha em regime de turno. Mesmo com as dificuldades foram relatados pontos positivos principalmente por se sentirem incluídos. Já as equipes táticas apontaram outras frentes como a dificuldade de relacionamento com as áreas periféricas da manufatura. Estas áreas não estão integradas à rotina de WCM, como por exemplo as áreas de TI e financeira, o que gera desconforto e até mesmo conflitos. Já na empresa $B$, as equipes mostraram-se mais abertas aos desafios, relatando que todas as mudanças causam desconforto, mas são necessárias para o atendimento de um objetivo maior.

Tanto a equipe tática quanto a operacional tiveram a mesma ação para suavizar as dificuldades com as equipes de controladoria. Capacitaram um colaborador específico da manufatura para ser funcionário da controladoria, com experiência na manufatura e auxiliando nas rotinas de WCM. As equipes de informática pontuaram que muitas vezes as iniciativas do WCM esbarram nas limitações de automação e isso gera transtornos, atrasos e possíveis paralisações de projetos que não podem ser concluídos por limitações tecnológica ou alto investimento.

Como as equipes operacionais recebem direcionamento do WCM nas duas empresas, existem quadros comunicativos com estas informações. Na empresa A essas informações muitas vezes aparecem nas reuniões diárias de trocas de turno e 
as equipes táticas as recebem nas reuniões de pilares. $\mathrm{Na}$ empresa $\mathrm{B}$, essas informações chegam nos encontros mensais e, para as equipes táticas da mesma forma que na empresa $A$, nas reuniões de pilares.

Nas entrevistas foi possível perceber muita similaridade entre as respostas dadas pelos entrevistados quanto nas observações realizadas durante a pesquisa. As dificuldades relatadas foram as mesmas verificadas na análise documental, em atas de reuniões de pilares ou apresentações de fechamento de auditorias. O que consolida o nível bronze dessas plantas, pois o que se espera de uma planta bronze é que o sistema seja construído de forma sólida e que os resultados sejam monitorados. Para o próximo passo destas plantas, o foco será a solidificação e sustentabilidade dos resultados, bem como a simplificação das rotinas das pessoas e maior interação entre as áreas periféricas à manufatura.

\subsection{ANÁLISE E DISCUSSÃO}

Observando os pontos conceituais e os pontos analisados em campo é possível encontrar similaridade entre eles, os quais são detalhados a seguir. Com o passar dos anos os estudos acadêmicos referentes a WCM foram aprimorados e as práticas foram absorvidas pelos princípios que se reestruturaram em pilares. No estudo de campo foram vistos no templo de WCM todos os pontos descritos nas práticas, princípios e pilares conceituais.

\subsubsection{Análise com base nas 6 práticas da WCM de Hayes e Wheelwright (1984)}

Hayes e Wheelwright (1984) descreveram a manufatura de classe mundial como um conjunto de seis práticas, sugerindo que o uso de melhores práticas levaria a um desempenho superior. Neste estudo será comparado o conceito proposto pelos autores e possíveis verificações em campo.

Em relação à primeira prática - habilidades e capacidades da força de trabalho, os autores relataram a importância das habilidades e capacidades da força de trabalho, com foco em aprendizagens, institutos de formação e acordos de cooperação com institutos técnicos vocacionais. Na empresa B esta prática é evidenciada de forma mais prática por parcerias com escolas técnicas da região e atualização periódica da mão de obra, visto que o processo produtivo requer mais qualificação técnica. Já na empresa A buscam-se colaboradores qualificados. 
De acordo com a segunda prática - gestão da competência técnica, a falta de competência técnica da equipe de gestão pode se tornar uma vilã, transformando o gerenciamento de fabricação de ponta um desafio significativo. A empresa $B$ tem esta prática bastante evidente. Já na empresa $A$ as pessoas da gestão devem se qualificar no nível superior em cursos de engenharia ou correspondentes.

A terceira prática - competição pela qualidade concentra-se principalmente no produto, tendo os clientes como os condutores de qualidade e enfatizando o desenvolvimento com a participação dos trabalhadores e garantindo as mudanças culturais que apoiam essa participação. $\mathrm{Na}$ empresa $\mathrm{A}$, que atua no ramo automotivo, o qual exige das empresas grande proximidade com os clientes, existem os EQF (Engenheiros de Qualidade do Fornecedor) que acompanham, avaliam e auxiliam quando necessário o desenvolvimento e o desempenho do fornecedor. Estas equipes de EQF treinam juntamente com as equipes internas. Já na empresa B a proximidade do cliente se dá pelo pilar da qualidade e controle de processos e visitas dos clientes na fábrica. A empresa B pode aprimorar esta mudança cultural, mesmo o grupo já tendo foco na proximidade com o cliente.

A quarta prática - participação da força de trabalho está relacionada à participação da força de trabalho, e o foco das ações relacionadas concentram-se em mudanças culturais e políticas que facilitem a participação e o envolvimento dos funcionários. No modelo do WCM da empresa ("templo de WCM"), tem-se "gestão autônoma" e "envolvimento de pessoas" como fundação, sendo o alicerce para todos os pilares. Tanto na empresa A quanto na empresa $B$ foi possível verificar as ações voltadas para esta participação, como por exemplo por meio das campanhas "sua ideia vale ouro" na empresa B, e o "desafio kaizen" na empresa A. A empresa B demonstrou maior participação dos colaboradores com ideias de melhorias de processos, e na empresa A os colaboradores mostraram -se mais corretivos frente aos problemas.

A quinta prática - reconstrução da engenharia industrial descreve 0 desenvolvimento interno de equipamentos com características únicas, que é difícil para os concorrentes copiarem. Esta prática também enfatiza a importância de desenvolver a capacidade de os funcionários manterem e melhorarem seus próprios equipamentos, bem como de desenvolverem o senso de propriedade do equipamento. O grupo tem uma empresa específica (SEVA) para o desenvolvimento de equipamentos próprios para garantir maior confidencialidade ao processo. Para o 
senso de propriedade do equipamento tem-se na fundação do templo de WCM a gestão autônoma que prega exatamente o conceito "da minha máquina cuido eu". Foi observado que a prática da gestão autônoma está mais visível na empresa $B$, inclusive, pelas entrevistas realizadas esta prática foi citada algumas vezes em especial pela equipe operacional, porém há evidências desta prática nas duas empresas. Apesar de pouco citada na empresa A, foi possível observar pela área as etiquetas de gestão autônoma sinalizando anomalias nos equipamentos.

A sexta prática - abordagem de melhoria incremental trata de abordagens de competitividade, ou abordagens incrementais de melhoria da concorrência. Os autores sugerem que os concorrentes de classe mundial buscam a melhoria contínua em pequenos incrementos, cujo objetivo é vencer a corrida criando um padrão em constante crescimento. Foi possível observar esta prática na estratégia do grupo como empresa inovadora e líder de mercado, onde o WCM é praticado para tornar isso possível com todas suas ferramentas, em especial o GRID de auditoria que contempla esta prática no requerimento chamado "visão".

Foi possível verificar que as práticas estão presentes na essência das empresas estudadas pelo alinhamento com as diretrizes do grupo, onde o programa de WCM viabiliza o alcance destas práticas.

\subsubsection{Análise com base nos 16 princípios de Schonberger (1986)}

Os 16 princípios descritos por Schonberger (1986) são frutos do aperfeiçoamento de seus estudos, que resultou na ampliação dos pontos conceituais da WCM. É notória a semelhança entre as empresas A e B, pois ambas seguem o mesmo GRID de auditoria de WCM. Assim, como seria esperado, guiam-se pelas mesmas diretrizes, com pequenas particularidades.

Os princípios 1 e 2 referem-se aos clientes, sendo o primeiro relacionado a importância de juntar-se aos clientes organizando-se por famílias de clientes ou até mesmo por tipo de produto e o segundo com foco na captura de informações, que se bem identificadas e trabalhadas podem permitir que a empresa atue de maneira competitiva na seleção e aplicação de práticas relacionadas a estes clientes. As empresas estudadas, dentro dos seus respectivos ramos de atuação, já possuem 
seu nicho de clientes, pois seus produtos são específicos para uma aplicação direcionada.

Na empresa A foi possível notar divisão de seus produtos por famílias, sendo classificadas em duas macros famílias referentes as características dos processos e três subfamílias de acordo com as características especificas do produto, como exemplo as macros famílias vidros laminados e temperados e as subfamílias parabrisas, laterais, vigias e. Como no ramo automotivo os fornecedores trabalham muito próximos dos clientes pois a competitividade do fornecedor colabora para melhor desemprenho do seu cliente, existem os EQF, que são os engenheiros de qualidade do fornecedor que acompanham, avaliam e auxiliam quando necessário o desenvolvimento e desempenho do fornecedor, no caso a empresa estudada.

A empresa $B$ também tem seus produtos segmentados por família, inclusive galpões de fabricações diferentes, seguindo os mesmos princípios da empresa As macros famílias segmentadas por tipo de processos e micro famílias diferenciadas pelas dimensões dos produtos, sendo estes fundição e centrifugação e os produtos respectivos, válvulas e tubos tendo seus diâmetros pequenos, médios e grandes. A empresa $B$ tem em maior parte de seus clientes empresas públicas, logo o poder comercial é menor por serem licitações. Para manter esta proximidade e entender as necessidades técnicas dos potenciais clientes a empresa B promove academias com treinamentos técnicos abertos a empresas e universidades e desta forma divulga seus produtos e capacita o mercado para utilização dos mesmos.

Associando estes princípios ao templo de WCM das empresas estudadas, primeiramente, o grupo tem em seus valores cinco atitudes que servem como um guia aos seus colaboradores, sendo a primeira "cultivar a proximidade com o cliente" que pode ser observada na análise documental do GRID de auditoria no item visão.

O princípio 3 se refere à qualidade, considerando a importância da melhoria contínua, flexibilidade e tempo de resposta. Nas observações das duas empresas o programa de WCM como um todo visa a melhoria continua tendo em seus pilares qualidade e controle de processos, o compromisso com a qualidade do produto e a melhoria continua no processo produtivo. Assim, como o pilar foco no cliente e serviço trata das melhorias para atender a flexibilidade solicitada pelo mercado e tempo de resposta. A empresa A mostrou-se mais adaptada a flexibilidade pelo mercado de atuação e a empresa $B$ a flexibilidade se dá por serem equipes fixas 
que atuam em diferentes máquinas, sendo direcionadas pela programação de produção.

O princípio 4 refere-se ao envolvimento dos funcionários da linha de frente em aspectos estratégicos do planejamento da empresa. Nas empresas $A$ e $B$, os funcionários envolvidos diretamente nos aspectos estratégicos são os funcionários de níveis diretivos e táticos em reuniões de comitês, cabendo as equipes operacionais serem informadas das decisões tomadas. As equipes operacionais podem propor melhorias ou sugestões via programas de envolvimento. Na empresa A o programa é denominado "desafio kaizen" e na empresa B o programa é denominado "sua ideia vale ouro". Este item pode ser verificado no GRID nos cadernos de gestão da estratégia e envolvimento de pessoas.

O princípio 5 trata da redução de alguns fornecedores, bem como de componentes e operações. Pensando que o programa de WCM nas empresas A e B faz parte de um programa ainda maior (WCSC), este trabalho com os fornecedores é feito primeiramente com esta equipe e as ações são desdobras às equipes de compras (WCP - Wolrd Class Purchase) locais para trabalharem junto a manufatura esta satisfação de seus fornecedores e redução de opções, focado numa linha mais enxuta de trabalho.

O princípio 6 aborda a redução dos tempos de fluxo, de setup e de inicialização ao longo da cadeia. Este princípio é abordado no mapa de fluxo de valor que é parte da fundação de todos os pilares. O tempo de setup é tratado pelo pilar de eficiência industrial e a quantidade de setup é tratado no pilar de foco no cliente e serviço, um pilar mais próximo da logística da fábrica. Desta forma há a interação entre os pilares.

O princípio 7 trata de uma proximidade com o cliente considerando taxa de uso ou demanda. Este princípio é evidenciado em sua totalidade no pilar de foco no cliente e serviço juntamente com a equipe de logística.

Outro princípio relacionado à recursos humanos é o princípio 8, que trata da importância de capacitar continuamente estes recursos considerando aspectos como, por exemplo, rotatividade de função, desenvolvimento de carreira e até mesmo segurança. Ainda com relação à recursos humanos, o princípio 9 se refere ao reconhecimento dos funcionários por meio de recompensas e até mesmo de celebrações para favorecer a contribuição dos mesmos para com a empresa. No templo de WCM tem-se o pilar de desenvolvimento de pessoas, que tem como 
ferramenta principal a matriz de competências que está voltada para capacitação da mão de obra. Na fundação do templo tem-se o envolvimento de pessoas. Ambos estão nos GRID de auditoria com seus respectivos cadernos, além de um caderno específico para recursos que contempla a parte de carreira e remuneração.

O princípio 10 trata da necessidade de reduzir ao máximo imprevistos e contratempos, enquanto o princípio 11 retoma às equipes da linha de frente considerando a importância destas equipes conhecerem detalhadamente os processos envolvidos, mantendo registros das informações. As observações para estes princípios no programa de WCM são prontamente vistas no pilar de qualidade e controle de processo em ferramentas específicas como a matriz QA (Quality Assurance) que tem seu objetivo de indicar a fase crítica do processo e o FMEA (Failure Mode and Effect Analysis) que faz a gestão de riscos e prevê possíveis falhas já indicando uma contramedida, além da fundação do templo contemplar o envolvimento de pessoas e padronização. $\mathrm{Na}$ empresa A estes princípios mostraram-se mais sólidos e rápidos devido ao acompanhamento e proximidade do cliente. Já na empresa B pode ser verificado apenas em matérias de pilares, mas não tão intensamente quanto na rotina da empresa $A$ que trata estes itens nas reuniões diárias matinais com o auxílio de uma planilha denominada "fast response" de acompanhamento pelo cliente e pela equipe de manufatura.

O princípio 12 sugere o controle de custo por meio da redução de transações, de relatórios e da simplificação da comunicação. Este princípio é visto no templo de WCM em sua fundação na estratificação de custos. Na empresa A este item é visto no comitê diretivo, não sendo possível verificar em nível tático ou operacional. Já na empresa $B$ a estratificação dos custos é usada para todas as tomadas de decisão dos pilares. Um princípio bem ativo na empresa $B$.

$\mathrm{Na}$ sequência, o princípio 13 foca no desempenho percebido pelo cliente considerando indicadores como, por exemplo, qualidade, velocidade e flexibilidade. Tanto na empresa A quanto na empresa B existem o alerta de qualidade que é a comunicação direta sobre a satisfação dos clientes. O pilar de qualidade tem um KPI prioritário denominado reclamação de cliente e o pilar de foco no cliente e serviço mede os indicadores de velocidade e flexibilidade. Em nenhuma das empresas foi possível verificar esta visão senão dentro do pilar.

O princípio 14 sugere a capacitação da equipe de trabalho ao invés da aquisição precoce de novos equipamentos ou até mesmo da automação. Ainda com 
relação às instalações de trabalho, e o princípio 15 recomenda que as mesmas sejam simples, de baixo custo, com flexibilidade de movimentação e que possam atender às famílias de produtos e clientes. Como visto na estratégia do grupo para o WCM o pilar de inovação é o último a ser lançado e recebe demanda dos demais pilares quando os mesmos alcançam capacidade técnica do equipamento. As duas empresas seguem estes critérios, e quando há invocação é por atualização via benchmark com plantas similares para adequação de processos. Quando há aquisições de novos equipamentos formam-se grupos multifuncionais de diferentes pilares para minimizar possíveis falhas, como não atendimento a alguma norma de segurança, não capacitação da mão de obra, saturação do equipamento ou gargalos do processo.

Por fim, o princípio 16 promove a importância de aumentar a capacidade da organização, favorecendo os demais princípios. Em campo foi possível observar nas empresas A e B que o programa de 5 S é fundamental para a eliminação de perdas por falta de organização. Na empresa B o programa de $5 S$ traz um apelo ainda mais forte para o foco nos processos.

Foi possível verificar que os princípios estão presentes no programa de WCM, que é o mesmo nas empresas $A$ e $B$, porém a maturidade de cada princípio pode ter diferença devido as particularidades do processo produtivo. Entenda-se por maturidade o tempo de prática do WCM e desenvoltura das equipes nos princípios. A maturidade caminha com o tempo e necessidade da empresa e das equipes?

\subsubsection{Análise com base nos 10 Pilares de Palucha (2012)}

O modelo dos 10 pilares da WCM descritos por Palucha (2012), foi considerado nessa análise, principalmente por ser usado como referência por grande número de empresas que buscam a estruturação da manufatura com base na WCM.

O pilar segurança refere-se principalmente à eliminação de acidentes por meio da melhoria contínua e ações preventivas intensas. Nas empresas A e B equivale ao pilar de saúde e segurança, que tem a meta de zero acidente e trabalha para melhoria da saúde ocupacional, como exemplo ergonomia. Este pilar conta com a participação em ações dos engenheiros de segurança do trabalho e médico do trabalho obrigatoriamente (diretrizes do grupo). 
O pilar desdobramento de custo tem como objetivo analisar as atividades que podem ser melhoradas $\mathrm{e}$, consequentemente melhore o resultado. $O$ pilar melhoria focada trabalha os problemas identificados no pilar de desdobramento de custo. Estes pilares nas empresas estudadas se mostraram com fundação do templo de WCM, onde tem-se a estratificação dos custos e a melhoria focada. Nas empresas estudadas, este pilar é um item da fundação do templo do WCM que é comum a todos os pilares e tem o mesmo propósito. Em ambas as empresas foi possível observar este objetivo ativo, porém na empresa B mostrou-se com maior maturidade e envolvimento na análise documental e entrevistas.

O pilar manutenção autônoma tem como objetivo principal a preservação do sistema produtivo e até mesmo a restauração de equipamentos, bem como da qualificação dos funcionários responsáveis pela manutenção. Este pilar nas empresas estudadas se mostrara com fundação do templo de WCM, onde tem-se a gestão autônoma. Nas empresas A e B este pilar é um item da fundação do templo do WCM que é comum a todos os pilares e tem o mesmo propósito. Em ambas as empresas foi possível observar este objetivo ativo.

Já o pilar manutenção profissional trata de problemas decorrentes da não identificação de problemas dos equipamentos e até mesmo da não qualificação dos profissionais responsáveis. Um dos objetivos deste pilar é trabalhar em colaboração com os responsáveis pelo pilar manutenção autônoma. No programa de WCM das empresas estudadas este pilar é equivalente ao pilar de confiabilidade que trata a saúde dos equipamentos.

O pilar controle de qualidade tem como objetivo que o produto chegue no cliente exatamente conforme o prometido. No programa de WCM das empresas estudadas este pilar é equivalente ao pilar de qualidade e controle de processos, sendo pilar prioritário na empresa $\mathrm{B}$.

O pilar logística e serviços aos clientes foca no fornecimento de condições adequadas de fluxo de materiais dentro da empresa e entre a empresa e seus fornecedores. Este pilar equivale ao pilar de foco no cliente e serviço liderado pelas equipes de logística das empresas A e B com o mesmo propósito.

O pilar gestão antecipada de equipamentos refere-se às atividades que possuem um tempo alto de setup, o que permite a otimização de custos e diminuição de desperdícios. Este pilar equivale ao pilar de eficiências industrial das empresas $A$ e $B$, com o mesmo propósito voltado para perdas de mão de obra e 
eficiência global do equipamento e eficiência energética. Na empresa A este pilar é considerado prioritário.

O pilar desenvolvimento de pessoas foca no treinamento e qualificação de todos os envolvidos na produção. Este pilar equivale ao pilar de desenvolvimento de pessoas, mesmo nome, e é liderado pelas equipes de recursos humanos das empresas A e B com o mesmo propósito.

Por fim, o pilar meio ambiente tem como objetivo principal atender aos requisitos ambientais. Este pilar é equivalente ao pilar de meio ambiente e redução de riscos, além do olhar para o meio ambiente trabalha na redução dos possíveis riscos das operações nas A e B.

Foi possível perceber grandes similaridades, pois a estrutura do WCM nas empresas observadas também trabalha com pilares e os objetivos conceituais que vão ao encontro do que foi observado em campo. O número de pilares é diferente, porem o tempo de WCM nas empresas estudadas contempla a fundação, que para o autor foi apresentada em pilares.

Com base nos achados da pesquisa de campo pode-se admitir que o uso de um dos três modelos referenciais de WCM é importante para guiar uma implementação. De fato, nas empresas estudadas cujo modelo adotado é uma customização do modelo dos 10 pilares, observou-se que tanto o modelo de Hayes e Wheelwringht (1984) como o modelo de Schonberger (1996) estão contemplados pelas práticas observadas nos dois casos estudados.

\subsubsection{Desempenho}

Tratando-se do objetivo principal do programa de WCM que é alcançar a competitividade global aderindo aos seguintes princípios: sem desperdício; sem estoque; sem falha; sem defeito; melhoria de processos aplicados; aumento de produtividade; segurança aprimorada; redução de custos.

Foi possível observar uma atenção especial a gestão de indicadores de desempenho que são direcionados para todos os níveis, sendo, operacional, tático e diretivo, respectivamente: OPI; KPI e KPI estratégico, sendo vinculado ao desdobramento da política. Os indicadores de desempenho estão amplamente divulgados por gestão visual direcionados ao púbico alvo. 
Pensando em equipe operacional é possível verificar tabelões localizados próximos aos postos de trabalho na empresa A e em menor proporção nos postos de trabalho da empresa $B$ devido a agressividade do processo. Porém há uma sala especial na empresa $B$ destinada a gestão visual dos indicadores de desempenho. Para o nível tático é possível verificar os tabelões com os indicadores de desempenhos nas salas destinadas ao WCM, pois grande parte da equipe tática é parte dos pilares de WCM.

Para o nível diretivo há um tabelão específico com o desdobramento da estratégia onde faz um link direto com os indicadores de desempenho dos pilares. $\mathrm{Na}$ empresa A há uma sala específica para o comitê diretivo e esta gestão visual dos indicadores de desemprenho estratégicos encontram-se nesta sala, enquanto na empresa B este tabelão fica também na sala de WCM, juntamente com os demais tabelões de pilares.

Foi possível verificar que os principais indicadores de desempenho comuns entres as empresas observadas estão relacionados aos pilares de "eficiência industrial", "qualidade e controle de processo" e "saúde e segurança", sendo estes OEE; produtividade; rendimento ou refugo (apesar da diferença de nomenclatura é o indicador tem a mesma essência que são as peças consideradas como ruins, ou viram refugo ou são destinadas ao retrabalho) e por último, mas não menos importante as taxas de acidentes, que tem a meta zero e procura-se rigorosamente cumpri-la.

Houve destaque pelos melhores desempenhos em indicadores técnicos e financeiros quando comparados aos períodos antecessores a implementação do programa de WCM e foi visto um processo contínuo de aprimoramento em seus processos para manterem-se competitivos, quando observado, no pilar foco no cliente e serviço relacionado grandemente as atividades da logística em conjunto com equipe comercial, o nível de atendimento ao mercado e o market share. 


\section{CONSIDERAÇÕES FINAIS}

Pelo estudo apresentado observou-se a implementação de um programa de WCM em relação às práticas, princípios, e pilares conceituais.

Mesmo evidenciados por análise documental que até o momento final do estudo de caso as empresas não alcançaram 100\% de implementação dos requisitos de WCM foi possível evidenciar cada prática, princípio e pilar conceituais, mesmo que em andamento.

Verificou-se que a cultura do WCM pode ser aplicada nas diferentes empresas, não sendo relevante o setor de atuação, pois foi verificado em documentos apresentados (de auditorias) as comparações entre diferentes negócios, países e plantas servindo para os líderes do programa de WCM como benchmarking, pois todas seguem o mesmo critério e GRID de auditoria WCM.

Neste ramo do estudo existem muitas oportunidades de melhoria, pois na metodologia WCM pelos dados apresentados existem muitas lacunas que ainda não foram exploradas. A exploração dessas lacunas pode melhorar a gestão da empresa para manterem-se sempre competitivas e diferenciadas no mercado no mercado de atuação.

Consolidando as observações do estudo em campo com os modelos conceituais foi possível observar que práticas em destaque nas observações na empresa A são referentes as práticas 3 e 6 relacionadas a qualidade e melhoria contínua, já na empresa $B$ as práticas 1,2 e 4 relacionadas a mão de obra de alguma forma.

A empresa A demonstrou maior maturidade, conforme as observações de documentos e entrevistas, nos princípios 1,2,7 e 13 que se relaciona com o cliente de alguma forma pois o mercado de atuação traz esta característica de relacionamento mais estreito entre fornecedor cliente.

A empresa A demonstrou maior maturidade, conforme as observações de documentos e entrevistas, nos princípios $4,8,9,11$ e 14 que se relaciona com a mão de obra de forma geral, pois o mercado de atuação necessita de maior qualificação técnica e envolvimento dos colaboradores de todos os níveis. 
Os pilares conceituais se mostraram mais próximos da estrutura observada nas empresas estudadas que também tem o WCM na figura de templo, porém as diferenças são o número de pilares, que o conceito aborda 10 e nas empresas temse 8 , e a fundação que nas empresas é algo que se mostrou significativo para o sucesso do WCM no modelo conceitual não é desenhado como fundação, mas o conteúdo faz parte dos pilares.

Todo este esforço das empresas observadas é para manterem-se competitivas motivados pela justificada do cenário mercadológico que se mostra um ambiente competitivo, em que estas buscam atender às necessidades dos clientes e ajustar os processos de produção aos requisitos de um mercado que visa eliminação de qualquer fonte de desperdício.

A contribuição deste estudo para teoria como visto no estudo bibliométrico ao número restrito de publicações sobre o tema WCM como o todo, e para a prática de como as empresas podem melhorar adotar a fundação para o WCM para auxilio da estrutura dos pilares.

As limitações do estudo se dá principalmente ao tema WCM ser amplo e não ter sido explorado as riquezas de detalhes em sua aplicação como nas áreas qualidade, manutenção, desenvolvimento de projetos e produtos, saúde e segurança, entre outras que não foram aprofundados neste estudo.

Ao longo do desenvolvimento deste estudo identificaram-se questões que permitem o desenvolvimento de estudos futuros para confirmação da aplicação da fundação do WCM uma potencial melhoria. Para isso é necessárias novas observações e de forma a agregar preferencialmente em empresas de diferentes segmentos para validação desta conclusão. 


\section{REFERÊNCIAS}

BROWN, S.; SQUIRE, B.; BLACKMON, K. The contribution of manufacturing strategy involvement and alignment to world-class manufacturing performance. International Journal of Operations \& Production Management, v. 27, n. 3, p. 282-302, 2007.

CARVALHO, M. M.; FLEURY, A.; LOPES, A. P. An overview of the literature on technology roadmapping (TRM): contributions and trends. Technological Forecasting and Social Change, v. 80, n. 7, p. 1418-1437, 2013.

CHIARINI, A.; VAGNONI, E. World-class manufacturing by Fiat. Comparison with Toyota Production System from a Strategic Management, Management Accounting, Operations Management and Performance Measurement dimension. International Journal of Production Research, v. 53, n. 2, p. 590-606, 2015.

DE FILIPPO, J.S. World-class manufacturing in Chengdu: a case study on China's first aviation joint venture. International Journal of Technology Management, v. 13, p. 681-694, 1997.

DIGALWAR, A.K.; JINDAL, A.; SANGWAN, K.S. Modeling the performance measures of world class manufacturing using interpreting structural modeling. Journal of Modelling in Management, v. 10, n. 1, p. 4-22, 2015.

EISENHARDT, K. M. Building theories from case study research. Academy of Management Review, v. 14, n. 4, p. 532-550, 1989.

FLYNN, B.B. et al. World-class manufacturing project: overview and selected results. International Journal of Operations \& Production Management, v. 17, n. 7, p. 671-685, 1997.

FREITAS, I.S.; BARROS FILHO, L.C. Diagnóstico da implementação da metodologia de gestão estratégica World Class Manufacturing (WCM) nas indústrias de Pernambuco. Revista de Engenharia e Pesquisa Aplicada, v 3, n. 1, p. 63-72, 2016.

GAJDZIK, B. World class manufacturing in metallurgical enterprise. Metalurgija, v. 52, n. 1, p. 131-134, 2013.

GHAURI, P. N.; GRONHAUG, K. Research Methods in Business Studies. London: Prentice Hall - 4th Edition, 2010.

GONÇALVES, F.F.; GUIMARÃES, I.A.D.; BAGNO, R.B. Manufatura de classe mundial (WCM) como uma jornada de mudança organizacional: o caso de uma rede de fornecedores da indústria automobilística. X EMEPRO - Encontro Mineiro de Engenharia de Produção, 2014.

HALEEM, A. et al. Analysis of critical success factors of world-class manufacturing practices: an application of interpretative structural modelling and interpretative 
ranking process. The Management of Operations, v. 23, n. 10-11, p. 722-734, 2012.

HARRISON, A. Manufacturing strategy and the concept of world class manufacturing. International Journal of Operations \& Production Management, v. 18 , n. 4 , p. $397-408,1998$.

HENDRY, L.C. Applying world class manufacturing to make-to-order companies: problems and solutions. International Journal of Operations \& Production Management, v. 18, n. 11, p. 1086-1100, 1998.

KETTER, S. World Class Manufacturing. métodos e instrumentos para o Fiat Group Automobiles Production System. Fiat Group, 2006.

LEAN INSTITUTE BRASIL. Lean thinking, 2019.

LOCKAMY, A.; COX, F. An empirical-study of division and plant performancemeasurement systems in selected world-class manufacturing firms - linkages for competitive advantage. International Journal of Production Research, v. 33, n. 1, p. 231-236, 1995.

LOPES, A.P.V.B.V.; CARVALHO, M.M. Evolution of the open innovation paradigm: towards a contingent cenceptual model. Technological Forecasting and Social Change, v. 132, p. 284-298, 2018.

MUDA, S.; HENDRY, L. Proposing a world-class manufacturing concept for the make-to-order sector. International Journal of Production Research, v. 40, n. 2, p. 353-373, 2002.

NEELY, A. The evolution of performance measurement research: developments in the last decade and a research agenda for the next. International Journal of Operations \& Production Management, v. 25, n. 12, p. 1264-1277, 2005.

PALUCHA, K. World class manufacturing model in production management. International Scientific Journal, v. 58, n. 2, p. 227-234, 2012.

PRASAD, S.; TATA, J. Publication patterns concerning the role of teams/groups in the information systems literature from 1990 to 1999. Information \& Management, v. 42, n. 8, p. 1137-1148, 2005.

SALAHELDIN, S.I.; EID, R. The implementation of world-class manufacturing techniques in Egyptian manufacturing firms - An empirical study. Industrial Management \& Data Systems, v. 107, n. 4, p. 551-566, 2007.

SAXENA, K.B.C.; SAHAY, B.S. Managing IT for world-class manufacturing: the Indian scenario. International Journal of Information Management, v. 20, p. 2957, 2000.

SCHONBERGER, R.J. World class manufacturing: the lessons of simplicity applied. The Free Press, Nova York, p. 1-17, 1986. 
SLACK, N.; CHAMBERS, S.; JOHNSTON, R. Administração da Produção. São Paulo: Atlas, 2002.

STOREY, J. HARRISON, A. Coping with World Class Manufacturing. Work Employment and Society, v. 13, n. 4, p. 643-664, 1999.

SUNNAPWAR, V.K.; KODALI, R. Development of a knowledge-based system for justification of world-class manufacturing systems. Proceedings of the Institution of Mechanical Engineers, v. 220, n. B10, p. 1751-1761, 2006.

VARGAS, S.M.Z.; VARGAS, A.M.S.; MILLAN, J.J.G. World class manufacturing in micro manufacturers of handmade wooden furniture industry in Puntalarga-Colombia. Pensamiento \& Gestión, v. 42, n. 1, p. 162-186, 2017.

VOSS, C.; BLACKMON, K. The impact of national and parent company origin on world-class manufacturing - Findings from Britain and Germany. International of Operations \& production Management, v. 16, n. 1, p. 98-115, 1996.

VOSS, C. A.; TSIKRIKTSIS, N.; FROHLICH, M. Case research in operations management. International Journal of Operations \& Production Management, v. 22, n. 2, p. 195-219, 2002.

VRAKKING, W.J.; MULDERS, P. The implementation of world-class manufacturing principles in smaller industrial companies - a case study from consulting practice. Technovation, v. 12, n. 5, p. 297-308, 1992.

WOMACK, J.P.; JONES, D.T.; ROSS, D. A máquina que mudou o mundo. Rio de Janeiro: Elsevier, 2004. 


\section{APÊNDICE A - ROTEIRO DE PESQUISA}

1. Perguntas orientadoras:

Questionário:

Nome:

Função:

Tempo de Casa:

Posto de Trabalho:

Descreva brevemente sua relacão com o WCM:

Perguntas Guiadoras Foco no WCM

1 Defina brevemente de forma simples o que é o WCM no seu entendimento.

2 Como você descreve o WCM na sua rotina?

3 Quais as principais ferramentas que você utiliza?

4 Há algum indicador que você acompanha? Pode me mostrar algum exemplo?

5 Quais os benefícios na sua rotina com WCM?

6 Quais as dificuldades do WCM em sua rotina?

7 Como você vê o direcionamento do WCM?

8 Como você participa do do WCM?

Análise documental:

Atentar-se aos documentos de auditorias e expostos nas áreas que reflitam as os conceitos - 6 práticas, 16 princípios e 10 Pilares. 